\title{
MAY 11964
}

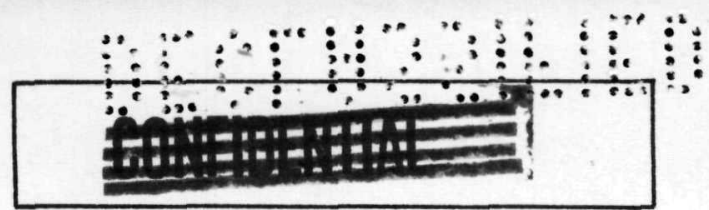

CLASSIFICATION LEVEL

(S, C, OR U)

ATOMICS INTERNATIONAL

A Division of North American Aviation, Inc.

Do not remove this sheet

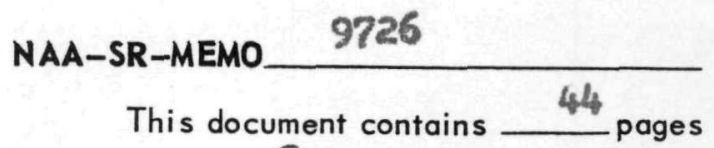

This is copy 9 of series

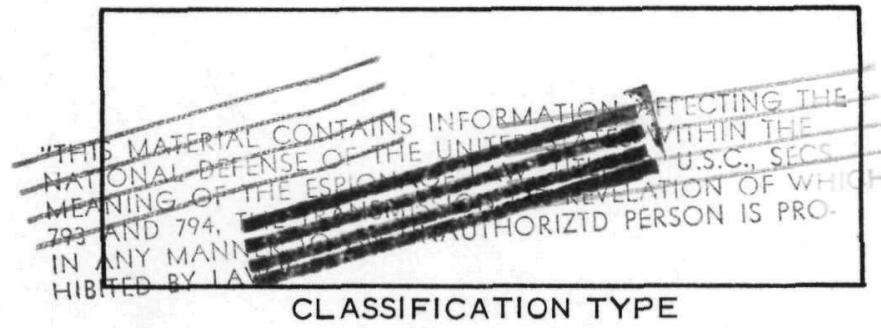

(RD OR DI)

$N A A-S R-M E M O s$ are working papers and may be expande

\section{modified, or withdrawn at any time,
and are intended for internal use only. \\ modified, or withdrawn at any time,
and are intended for internal use only.}

This report may not be published without the approval of the Patent Branch ABC.

\section{UNCLASSIEIED}

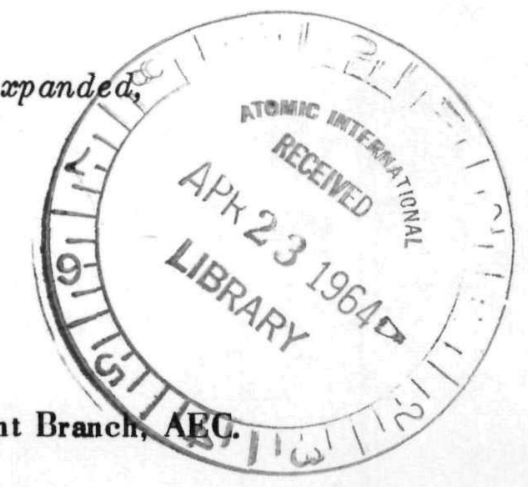

\section{Down raded at 12øys 1ntervalaz Not automatica11y declassifled}

\section{LEGAL NOTICE}

This report was prepared as an occount of Government sponsored work. Neither the United States, nor the Commission, nor any person acting on behalf of the Commission:

A. Makes any warranty or representation, express or implied, with respect to the accuracy, completeness, or usefulness of the information contained in this report, or that the use of any information, apperatus, method, or process disclosed in this report may not infringe privately owned rights; or

B. Assumes any liabilities with respect to the use of, or for damages resulting from the use of information, apparatus, method, or process disclosed in this report.

As used in the above, "person acting on behalf of the Commission" includes any om. ployee or contrector of the Commission to the extent that such employee or contractor prepares, handles or distributes, or provides access to, any information pursuant to his employment or contract with the Commission. 


\section{DISCLAIMER}

This report was prepared as an account of work sponsored by an agency of the United States Government. Neither the United States Government nor any agency Thereof, nor any of their employees, makes any warranty, express or implied, or assumes any legal liability or responsibility for the accuracy, completeness, or usefulness of any information, apparatus, product, or process disclosed, or represents that its use would not infringe privately owned rights. Reference herein to any specific commercial product, process, or service by trade name, trademark, manufacturer, or otherwise does not necessarily constitute or imply its endorsement, recommendation, or favoring by the United States Government or any agency thereof. The views and opinions of authors expressed herein do not necessarily state or reflect those of the United States Government or any agency thereof. 


\section{DISCLAIMER}

Portions of this document may be illegible in electronic image products. Images are produced from the best available original document. 
DEPT \& GROUP NO.

J. E. Bickel

$726-61$

\section{TITLE}

Startup and Shutdown Transients for the

SNAP-2 R/C and PCS Components

\begin{tabular}{|l|}
\hline $\begin{array}{l}\text { PROGRAM } \\
\text { Mercury } \\
\text { Rankine }\end{array}$ \\
\hline DISTRIBUTION \\
\hline Complete copies \\
\hline to each person \\
\hline on attached list. \\
\hline M. P. Berhold HQ2 \\
\hline d. B.GoodblattHQ2 \\
\hline V. Heiskala HQ2 \\
\hline L. James $\mathrm{HQZ}$ \\
\hline
\end{tabular}

SUBACCOUNT TITLE

Startup and Control Analysis

NAA-SR-MEMO
PAGE I OF 44
DATE 3-26-64
GO NO. 7562

\begin{tabular}{l|l} 
(CHECK ONE BOX ONLY) & (CHECK ONE BOX ONLY)
\end{tabular}

\begin{tabular}{ll|l|}
\hline UNCL. \\
\hline CONF. \\
\hline SECRET
\end{tabular}

STAIEMENT OF PROBLEM

1. Determine the effective emissivity and steady state heat losses of the SNAP-2 Primary system necessary to prevent mercury freezing at the time of mercury injection.

2. Determine the temperature transients of the SNAP-2 system after an orbital shutdown.

3. Determine the temperature transients of the CRU and injection tank if both are preheated before launch.

\section{ABSTRACT}

The orbital heating code (Reference 1 ) was used to determine the temperature transients discussed herein.

An effective primary system emissivity of 0.15 internal to the $R / C$ was found to be sufficient to insure that the PCS components and the $R / C$ are above the freezing point of mercury at injection. This value of emissivity results in a steady-state heat loss of $2.5 \mathrm{KW}$.

If the SNAP-2 system is shutdown while in orbit (constant sunconstant shade orbit), the mean $\mathrm{R} / \mathrm{C}$ temperature after 120 minutes was $35^{\circ} \mathrm{F}$ while the coldest $\mathrm{R} / \mathrm{C}$ node decays to $0^{\circ} \mathrm{F}$ in 100 minutes.

An additional study was the effect of preheating the CRU and injection tank to 700 and $500^{\circ} \mathrm{F}$, respectively, prior to launch. The resulting temperature of the CRU shaft was $225^{\circ} \mathrm{F}$ and the injection tank $140^{\circ} \mathrm{F}$ at mercury injection.
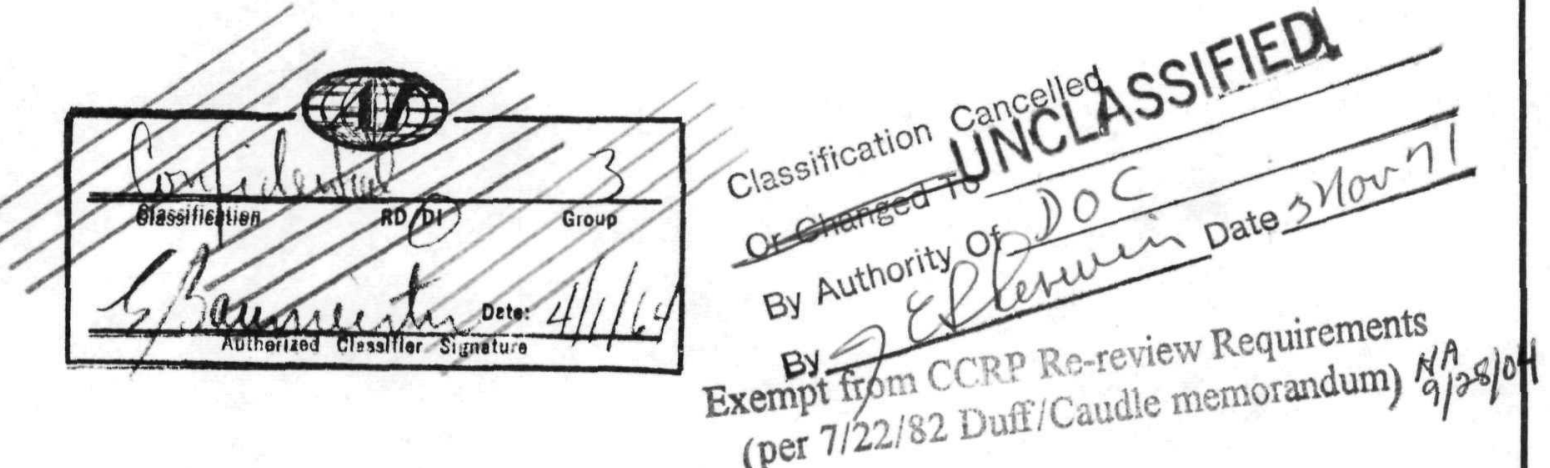


\section{ATOMICS INTERNATIONAL}

A Division of North American Aviation, Inc.

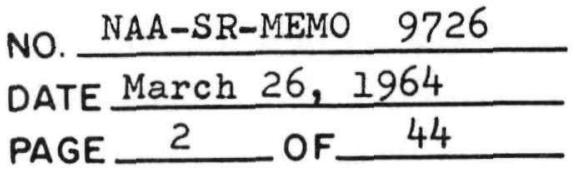

DISCUSSION

\section{Startup}

From the results presented in reference 1 , it was revealed that there was a strong possibility of mercury freezing in the $R / C$ at the time of injection. For the reference case presented (gold-coating on the $R / C$ subcooler and on all of the primary system), the temperatures of some portions of the $R / C$ were as low as $-120^{\circ} \mathrm{F}$ at injection.

Various cases were investigated in the referenced TDR to determine the feasibility of different methods of increasing the PCS components and the $R / C$ nodes above the freezing point of mercury at injection. At the time these studies were conducted, no correlation between the effective primary system emissivity and the steady state losses had been made. This relationship has since been obtained by utilizing the interchange factor code. (Reference 3) By assigning the predicted steadystate temperatures to the absorbing and radiating surfaces, this code determined the net heat transfer from these surfaces and also the temperature of the no-flux surfaces contained in the system. Various values of emissivity were input for the cold $\mathrm{NaK}$ leg, resulting in a relationship between the effective primary system emissivity and the steady state heat losses to the R/C. (See Figure 1) Where the effective emissivity is defined as

$$
E \text { eff }=\frac{E_{1} A_{1}+E_{2} A_{2}+\cdots \cdot E_{n} A_{n}}{A_{1}+A_{2}+\cdots A_{n}}
$$

The numbers $1,2, \cdots, \mathrm{n}$ are for the various $\mathrm{NaK}$ nodes which represent the primary system.

The current $\mathrm{R} / \mathrm{C}$ design is such that $3.17 \mathrm{KW}$ of primary loop heat loss can be accomodated at steady-state. This is the current design point of the radiator as per specification NR 7550-42, "Specification for SNAP-2 Design Point! The largest steady-state heat loss investigated in reference $l$ was that with no gold-coating on the cold $\mathrm{NaK}$ leg and resulted in a steady-state heat loss of $1.90 \mathrm{KW}$.

The orbital heating code was used to determine the effective emissivity of the primary system necessary to assure that none of the PCS components or $\mathrm{R} / \mathrm{C}$ nodes were below $0^{\circ} \mathrm{F}$ at the time of mercury injection. This conservative value (mercury freezes at approximately $-40^{\circ} \mathrm{F}$ ) was chosen to compensate for inherent analytical uncertainties. From these studies it was found that this condition can be attained with a steady-state heat loss of $2.5 \mathrm{KW}$. From Figure 1, this heat loss represents an effective primary system emissivity of 0.15 . It should be noted that this value of $2.5 \mathrm{KW}$ is less than the maximum allowed by the design point specification. The PCS components and R/C temperature transients are presented for this case in figures 2 through 17. These figures should be compared to and should supercede those presented in NR 7550-43, "Specification for SNAP-2 Orbital Startup." 


NO. $\frac{\text { NAA-SR-MEMO }}{9726}$
DATE $\frac{\text { March 26, } 1964}{3}$ OF
PAGE

A Division of North American Aviation, Inc.

Orbital Shutdown

Recent investigations of the orbital re-start capabilities of the SNAP-2 system have warrented a closer analysis of the temperature transients after an orbital shutdown. The orbital heating code was used for this analysis by assigning the normal steady-state temperatures as the initial component temperatures and by programming in the shutdown $\mathrm{NaK}$ system temperature transients. These NaK transients were calculated with the primary loop digital program. The system was assumed to be in a constant sun-constant shade orbit during this initial study.

The temperature transients for the mean $\mathrm{R} / \mathrm{C}$ temperature, coldest $\mathrm{R} / \mathrm{C}$ node, and primary loop are shown in Figure 18 through 20. All of the PCS components were well above the freezing point of mercury during this two hours.

\section{$\underline{C R U}$ and Injection Tank Heat Prior to Launch}

An additional study which was conducted with the orbital heating code was an estimation of the temperature transients of the CRU and injection tank assuming they were launched at $700^{\circ} \mathrm{F}$ and $500^{\circ} \mathrm{F}$, respectively, with no heat supplied after launch. The temperature transients from launch to startup for both components are shown by Figure 21 for a transient orbit. This graph indicates that ground preheating is only a partial alternative to orbital preheat of the CRU. However, this method would reduce the heating requirements for orbital preheat.

\section{Orbital Heating Code}

Presented below is the method of data preparation which supercedes that presented in TDR 9004. Replacement of this section was necessary because of refinements which were made in the orbital heating code.

\section{Data Preparation}

It is essential to the correct running of the program that the node data be entered in proper sequence. It is, therefore, suggested that the user write out his sequence according to the format below before attempting to prepare the data sheets. A sample node sequence follows the format.

$\begin{array}{cc}\frac{N O D E}{1-10} & \frac{\text { COMPONENT }}{R / C \text { Nodes }} \\ 11-20 & \text { sub-cooler nodes } \\ 21 & \text { top } \\ 22 & \text { bottom }\end{array}$


 OF 44}

$\mathrm{XX}$

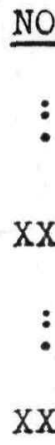

\section{COMPONENT}

internal components

:

$\mathrm{NaK}$ nodes

\author{
$\vdots$ \\ injection tank storage \\ CRU housing \\ CRU shaft \\ bracket I - first component \\ bracketed \\ bracket 2 - first component \\ bracketed \\ bracket 3 - first component \\ bracketed \\ bracket 4 - first component \\ bracketed \\ bracket 1 - second component \\ bracketed
}

Nodes 1-22 are always in the same order. The number of radiating internal nodes may be added to rearrange, etc., but must always follow the bottom node (22). All internal components classified as $\mathrm{NaK}$ nodes must be together and be the last of the internal components listed. This order also applies when preparing data sheets for the interchange factor code by $M$. P. Berhold. Punched output from the program is used as input to this code. The number of nodes at this point is the total which require the interchange factor data.

Immediately below the $\mathrm{NaK}$ nodes are the injection storage tank, CRU housing, and CRU shaft followed by the bracket nodes (4) for each component attached to the wall. 
Sample Case*

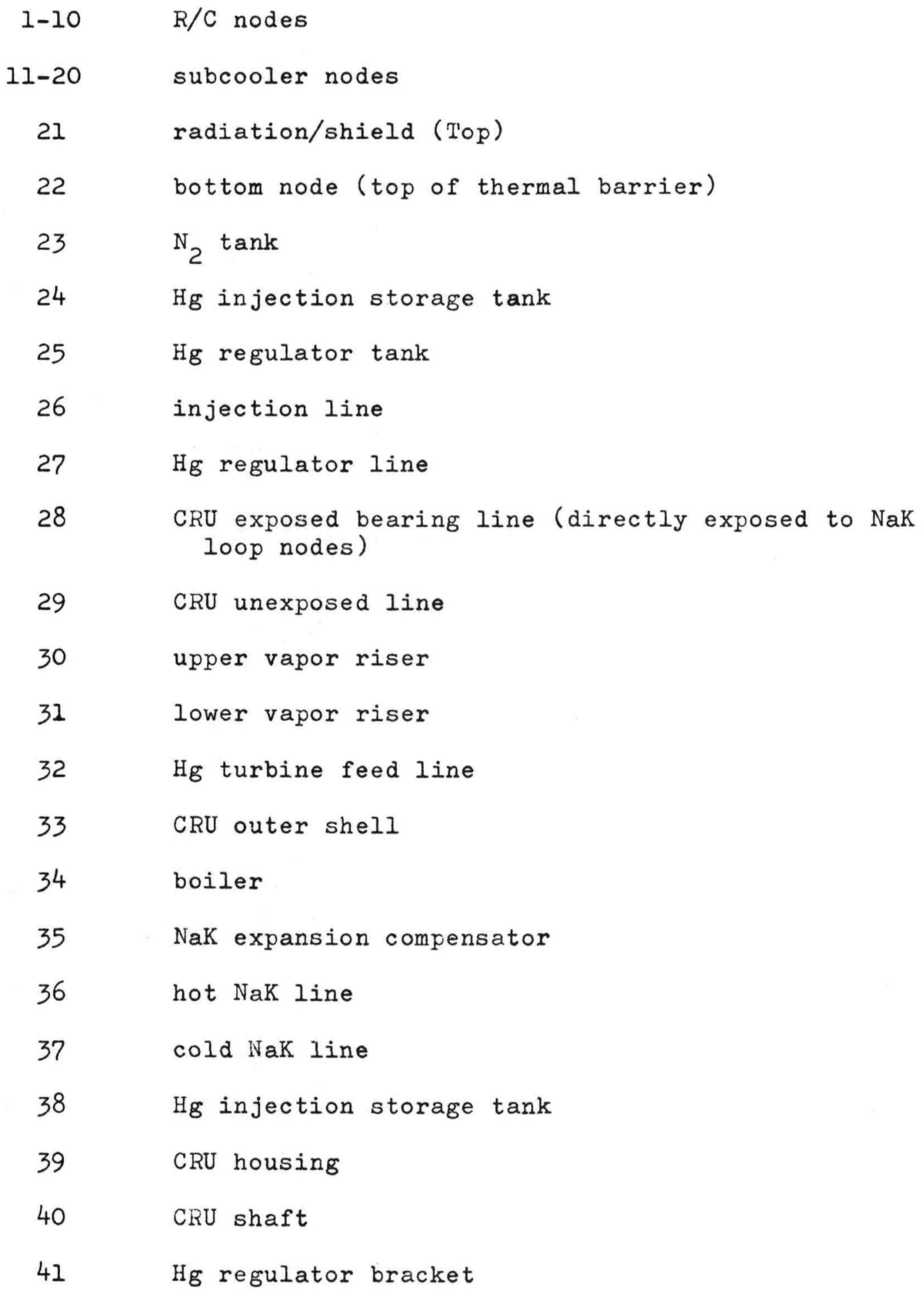

* Node sequence defined here applies to sample data sheets attached. 


\section{Sample Case (Continued)}

42 Hg regulator bracket

$43 \quad \mathrm{H}_{\mathrm{g}}$ regulator bracket

$44 \mathrm{Hg}$ regulator bracket

45 CRU bracket

46 CRU bracket

$47 \quad$ CRU bracket

48 CRU bracket

49 Hg injection tank bracket

$50 \quad \mathrm{Hg}$ injection tank bracket

51 Hg injection tank bracket

52 Hg injection tank bracket

Secondly, and prior to filling out the data sheets, if plotting is desired the user should decide which nodes (by number) are to be put on each graph. A maximum of 14 nodes may be plotted in any manner, i.e., all one graph, one per graph, two, three, etc. A sample plot set up is shown below and applies to the case used which is attached.

$\begin{array}{lll}\text { Plot } 1 & \text { node } & 24 \\ & & 38 \\ \text { Plot 2 } & \text { node } & 33 \\ & & 39 \\ & & 40 \\ \text { Plot } 3 & \text { node } & 25 \\ & & 27 \\ \text { Plot } 4 & \text { node } & 28 \\ & & 29 \\ & & 23 \\ & & 26 \\ & & 32\end{array}$

Plot 5 node 30

$$
31
$$

In preparing the data in the IP array, enter a zero for nodes not to be plotted and enter the plot number for those to be plotted. A single node may be placed on one graph only. 


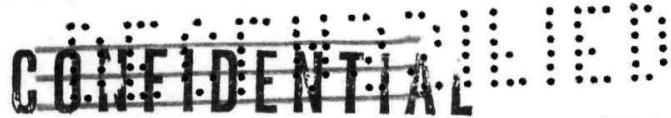

ATOMICS INTERNATIONAL

A Division of North American Aviation, Inc.

\begin{tabular}{l} 
NO. $\frac{\text { NAA-SR-MEMO } 9726}{\text { DATE March } 30,1964}$ \\
PAGE $7 \quad$ OF 44 \\
\hline
\end{tabular}

For each case the input data consists of two parts:

1. A title card containing up to 72 alpha-numeric characters describing the case.

2. The decimal case data. The program uses the FøRTRAN DECRD routing. Each piece of data has an index assigned to it from an array (defined on following pages). The index of the first piece of data on a card is entered to the far right of the first field (using FORTRAN FIXED 10 DIGIT DECIMAL DATA sheets). Data are then entered in numerical order by index filling the card. The last card of data in each case must contain a minus in columnone.

If the user wishes to run more than one case at a time, it is necessary to have the title card and at least one data card. The user needs only to enter the data that is changing from the previous case.

Sample data sheets are attached.

NUMERICAL EQUATION PROGRAM

DATA INDEX SYMBOL

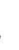

2

3

4

5

6

7
NPASS

NIN

IS $\varnothing \mathrm{RCS}$

ID $\varnothing \mathrm{RT}$

NAKN

IPL $\varnothing \mathrm{T}$

NAVGT
DESCRIPTION

$=0$, data entered, printed, and plotted as a function of time; $=1$, data as a function of revolution

$=0$, sun-shade orbit; $=1$, constant sun-constant shade orbit

if ID $\varnothing \mathrm{RT}=0$, enter time in even number of revolutions at end of case

number of internal components which have radiation term requiring intercahnge factor code data plus top and bottom

number of $\mathrm{NaK}$ components ( $(2 \mathrm{IO})$

$=0$, no CRT plotting will be done (all data below applicable to plotting need not be entered); $=1$, CRT plotting is desired

node number assigned to component being used as reference node in computing $R / C$ average temperature 
PAGE 8 OF 44

\begin{tabular}{|c|c|c|c|}
\hline $\begin{array}{l}\text { NUMERICAL } \\
\text { DATA INDEX }\end{array}$ & $\begin{array}{l}\text { EQUATION } \\
\text { SYMBOL }\end{array}$ & $\begin{array}{r}\text { PROGRAM } \\
\text { S YMBOL } \\
\end{array}$ & DESCRIPTION \\
\hline 8 & & INIT & $\begin{array}{l}=0 \text {, initial temperatures of com- } \\
\text { ponents are all equal except top; } \\
=1 \text {, initial temperatures vary for } \\
\text { some or all components; }=2 \text {, pro- } \\
\text { gram will pick up last values of } \\
\text { previous case (this option allows } \\
\text { the user to split the CRT plots of } \\
\text { the nodes if desired, that is the } \\
\text { only purpose of the option and it } \\
\text { is suggested it not be used other- } \\
\text { wise as it requires extra computer } \\
\text { time). Note: must be =l if shut- } \\
\text { down case. }\end{array}$ \\
\hline 9 & & NPL $\varnothing \mathrm{T}$ & $\begin{array}{l}\text { enter even number of hour or rev- } \\
\text { olution (depending on ID } \varnothing \mathrm{RT} \text { ) to } \\
\text { begin the continuous plots of } \\
\text { node temperatures. }\end{array}$ \\
\hline 10 & & NCON2 & $\begin{array}{l}=0, \text { CRU outer shell and injection } \\
\text { tank storage varies; }=2 \text {, CRU } \\
\text { varies, injection tank storage } \\
\text { constant; }=3 \text {, both vary. }\end{array}$ \\
\hline 11 & & INJ & $\begin{array}{l}\text { node number assigned to injection } \\
\text { tank }\end{array}$ \\
\hline 12 & & ICRU & node number assigned to $\mathrm{CRU}$ \\
\hline 13 & & $\operatorname{IC} \varnothing \mathrm{N}$ & $\begin{array}{l}\text { number of brackets or nodes } \\
\text { attached to the } \mathrm{R} / \mathrm{C}(\leq 10)\end{array}$ \\
\hline 14 & & ISHUT & $=0$, startup case; $=1$, shutdown \\
\hline
\end{tabular}

$15-20$

21

IBRAC

node number assigned to first $(1,1)$ component bracketed to the $\mathrm{R} / \mathrm{C}$

22

IBRAC $(2,1)$

node number assigned to upper section of $\mathrm{R} / \mathrm{C}$ to which component conducts heat. of subcooler to which component conducts heat 


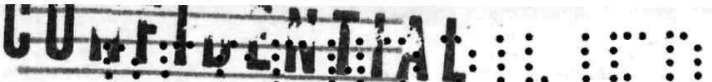

NÖ: HAs-8R-MEMO 9726

ATOMICS INTERNATIONAL

A Division of North American Aviation, Inc.

DATE March 30, 1964

PAGE 9 OF 44

\begin{tabular}{lccc}
$\begin{array}{l}\text { NUMERICAL } \\
\text { DATA INDEX }\end{array}$ & $\begin{array}{c}\text { EQUATION } \\
\text { SYMBOL }\end{array}$ & $\begin{array}{c}\text { PROGRAM } \\
\text { SYMBOL }\end{array}$ & DESCRIPTION \\
\hline 24 & $\begin{array}{c}\text { IBRAC } \\
(1,2)\end{array}$ & $\begin{array}{l}\text { same as IBRAC }(1,1) \text { for second } \\
\text { bracket node }\end{array}$ \\
$\vdots$ & $\vdots$ & \\
$\vdots$ & $\vdots$ & \\
50 & IBRAC & \\
& $(3,10)$ &
\end{tabular}

$51-90$

91

DTIME

time increment for calculations in minutes

$92(m c)_{i}^{(15)}$

AMCRC

(1)

product of mass and specific heat (16)

$93(\mathrm{mc})_{i+\cdots}$

AMCRC

product of mass and specific heat

$94 \quad(K A)_{1}^{(15)}$

$\mathrm{AK}$ (1)

product of heat transfer coefficient and cross-sectional area for: $R / C$ nodes

$95(K A)_{3}^{(16)}$

$96(K A)_{2}^{(15+16)}$

$97 \alpha_{s}^{(i s+16)}$

$98 \alpha_{s}^{(15+16)}$

$99{ }_{\left(\varepsilon_{T}\right)^{(1 s+16)}}$

AK (2) sub cooler nodes

AK (3) $\quad R / C$ and subcooler nodes vertically

ALPHAS

(1)

ALPHAS for subcooler nodes

EPSI

absorbtivity to thermal radiation (emissivity of outside area)

100

ANG I

angle of launch in relation to sun if the sun-shade orbit is being considered $\left(0^{\circ}\right.$ is directly into sun $0^{\circ}+$ to $180^{\circ}$ is moving away from the sun, and $180^{\circ}+$ to $360^{\circ}$ is approaching sun)

\footnotetext{
the $\Delta \mathrm{X}$ shown in equation is constant and therefore built into the code.
} 


\begin{tabular}{lccc} 
NUMERICAL & EQUATION & PROGRAM & \\
DATA INDEX & SYMBOL & SYMBOL & DESCRIPTION \\
\hline
\end{tabular}

101

$T \varnothing R$

102

TRAMI

frequency of $R / C$ and subcooler profile plots (enter in minutes or fractions of revolutions depending on ID $\varnothing \mathrm{RT}$ ) note: plot will be done every TOR minutes or revolutions - value has been set on test case such that one set of profiles before temperature ramp is given and in second case following the ramp (second case is continuation of first, see data sheets)

time in minutes at which the $\mathrm{NaK}$ nodes temperatures are raised by constant specified in array below*

104

TRAM3

time at which temperature ramp of NaK nodes begins - enter in minutes*

time in minutes when temperature ramp of $\mathrm{NaK}$ nodes ends and temperatures become constant again*

startup time of temperature ramp for the top of the $R / C$ given in minutes*

termination time for ramp of top in minutes*

rate of increase of top during ramp period - enter in BTU/hour

108

CUT

time in minutes to stop plotting

TAU ( $\because$ time at end of case)

time constant in shutdown caseenter in minutes

* in figuring time use 107 minutes/revolution 


\section{CDHHOEHTH}

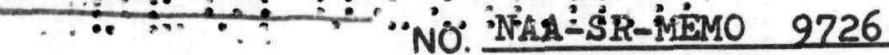

\section{ATOMICS INTERNATIONAL}

DATE March 30, 1964

A Division of North American Aviation, Inc.

PAGE 11 OF 44

\begin{tabular}{|c|c|c|c|}
\hline $\begin{array}{l}\text { NUMERICAL } \\
\text { DATA INDEX }\end{array}$ & $\begin{array}{l}\text { EQUATION } \\
\text { SYMBOI }\end{array}$ & $\begin{array}{l}\text { PROGRAM } \\
\text { SYMBOL }\end{array}$ & DESCRIPTION \\
\hline 111 & $(m c)_{i}^{(18)}$ & $\begin{array}{l}\text { AMC } \\
(1)\end{array}$ & $\begin{array}{l}\text { product of mass and specific } \\
\text { beat for bottom node (node } 22 \text { ) }\end{array}$ \\
\hline 112 & & $\begin{array}{l}\text { AMC } \\
(2)\end{array}$ & $\begin{array}{l}\text { product of mass and specific } \\
\text { heat for first internal node } \\
\text { specified (node 23) }\end{array}$ \\
\hline & & & $\begin{array}{l}\text { Enter order of nodes user has } \\
\text { specified, the mc of each } \\
\text { internal node except NaK nodes. } \\
\text { Then immediately following the } \\
\text { mc of the last internal node, } \\
\text { in the same array, enter data } \\
\text { as follows: }\end{array}$ \\
\hline
\end{tabular}

$(m c)_{i}^{(24)}$

AMC

$(\mathrm{XX})$

AMC

$(m c)_{i}^{(21)}$

$(\mathrm{XX}+1)$

$(m c)_{i}^{(22)}$

140

$141 \quad A_{i}^{(16)}$

$142 \quad A_{i}^{(18)}$

AMC

$(x x+2)$

AMC

(30)

AREA

(1)

AREA

(2)

$(E A)_{12}^{(23+24)}$

AREA

$(\mathrm{XX})$

$(\varepsilon A)_{12}^{(20+21)}$

$(E A)_{23}^{(21+22)}$ product of mass and specific heat. for injection storage tank

product of mass and specific

heat for CRU housing

for CRU shaft

(see sample data case)

area of bottom in $\mathrm{ft}^{2}$ (node 22)

area of first internal component specified (node 23)

Enter same order as the me's the area of each internal component. Then again in the same order for the remainder of the AREA array enter values equal to the product of the emissivity and area for that particular component.

product of emissivity and area for injection tank storage

product of emissivity and area for CRU housing

product of emissivity and area for CRU shaft

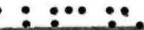




\begin{tabular}{|c|c|c|}
\hline $\begin{array}{l}\text { NUMERICAI } \\
\text { DATA INDEX }\end{array}$ & $\begin{array}{l}\text { EQUATION } \\
\text { SYMBOL }\end{array}$ & $\begin{array}{c}\text { PROGRAM } \\
\text { SIMBOL }\end{array}$ \\
\hline 170 & & $\begin{array}{l}\text { AREA } \\
(30)\end{array}$ \\
\hline 171 & Q & $\begin{array}{c}Q C \varnothing N \\
(1)\end{array}$ \\
\hline 172 & & $Q C \not N$ \\
\hline
\end{tabular}

173

200

$201-2700$

2701

QCळN

QC $\varnothing \mathrm{N}$

(30)

FSCRIP heat being added to first

internal component in BTU/hr. if necessary to prevent freezing component exclusive of $\mathrm{NaK}$ nodes

\section{DESCRIPTION}

TI

TI

(2)

TI

(3) heat being added to last internal

these values are punched directly from interchange factor of code in proper format (see deck set up) if INIT $=0$, $T I(I)$ equals initial temperature of all components except the top; if INIT $=1$, TI(1) equals initial temperature of first node; if INIT $=2$, the TI array need not be entered at all values must be entered in shutdown case.

if INIT $=0$, $T I(2)$ equals initial temperature of the top; if INIT $=1$, $T I$ (2) equals initial temperature of node 2

remainder of array needs to be entered only if INIT $=1$

initial temperature of node 3

must have initial temperature specified for all components, brackets, etc.

2790

TI

(90) 


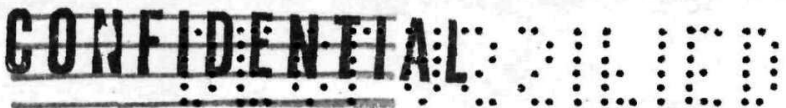

NO. NAA-SR-MEMO 9726

ATOMICS INTERNATIONAL

A Division of North American Aviation, Inc.
DATE March 30, 1964

PAGE 14 OF 44

\begin{tabular}{|c|c|c|c|}
\hline $\begin{array}{l}\text { NUMERICAL } \\
\text { DATA INDEX }\end{array}$ & $\begin{array}{c}\text { EQUATION } \\
\text { SYMBOL } \\
\end{array}$ & $\begin{array}{r}\text { PROGRAM } \\
\text { SYMBOLL } \\
\end{array}$ & \\
\hline 2940 & & $\begin{array}{l}\text { AMCB } \\
(4,10)\end{array}$ & \\
\hline 2941 & & $\begin{array}{l}\text { EAREA } \\
(1,)\end{array}$ & $\begin{array}{l}\text { product of } \\
\text { for first } \\
\text { first compc } \\
\text { to } R / C \text {. }\end{array}$ \\
\hline 2942 & & $\begin{array}{l}\text { EAREA } \\
(2,1)\end{array}$ & for second \\
\hline 2943 & & $\begin{array}{l}\text { EAREA } \\
(3,1)\end{array}$ & for third \\
\hline 2944 & & $\begin{array}{l}\text { EAREA } \\
(4,1)\end{array}$ & for fourth \\
\hline
\end{tabular}

2945

EAREA

for first node of second compon-

$(1,2)$

ent attached to $\mathrm{R} / \mathrm{C}$

2980

EAREA

$2981 \quad(K A / \Delta x)_{1-2}^{(25+26)}$

$(4,10)$

AKX

$(1,1)$

DESCRIPIION

(1)


Dणम+या।

NO. NAA-SR-MEMO 9726

ATOMICS INTERNATIONAL

A Division of North American Aviation, Inc.

DATE March 30, 1964

PAGE

15

OF

44

\begin{tabular}{llll}
$\begin{array}{l}\text { NUMERICAL } \\
\text { DATA INDEX }\end{array}$ & $\begin{array}{c}\text { EQUATION } \\
\text { SYMBOL }\end{array}$ & $\begin{array}{c}\text { PROGRAM } \\
\text { SYMBOL }\end{array}$ & DESCRIPTION \\
\hline \multirow{2}{*}{2986} & $\begin{array}{l}\text { AKX } \\
(1,2)\end{array}$ & $\begin{array}{l}\text { same as AKX }(1,1) \text { for second } \\
\text { node bracketed to wall }\end{array}$ \\
3030 & & & \\
& & &
\end{tabular}

Desk Set Up

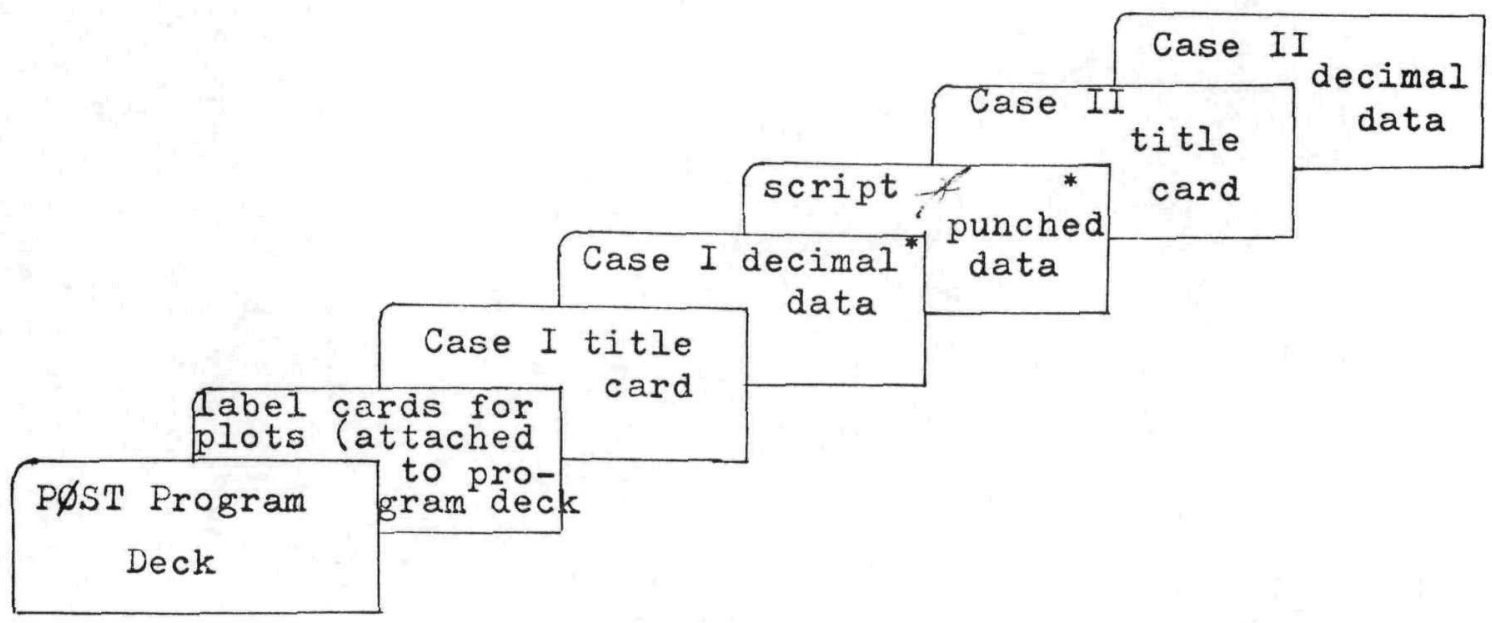

* The script fata has a minus in column one of the last card.

The user does not need one for the first case and must allow for the script f data deck to follow has decimal data. 

ATOMICS INTERNATIONAL
A Division of North American Aviation, Inc.
NO. NAA-SR-MEMO 9726
DATE March 30,1964

\section{REFERENCES}

1. J. Bickel- TDR 9004, "SNAP-2 R/C and PCS Component Temperatures prior to launch."

2. P. Gresho and M. P. Berhold (not published), "Interchange Factor Code." 


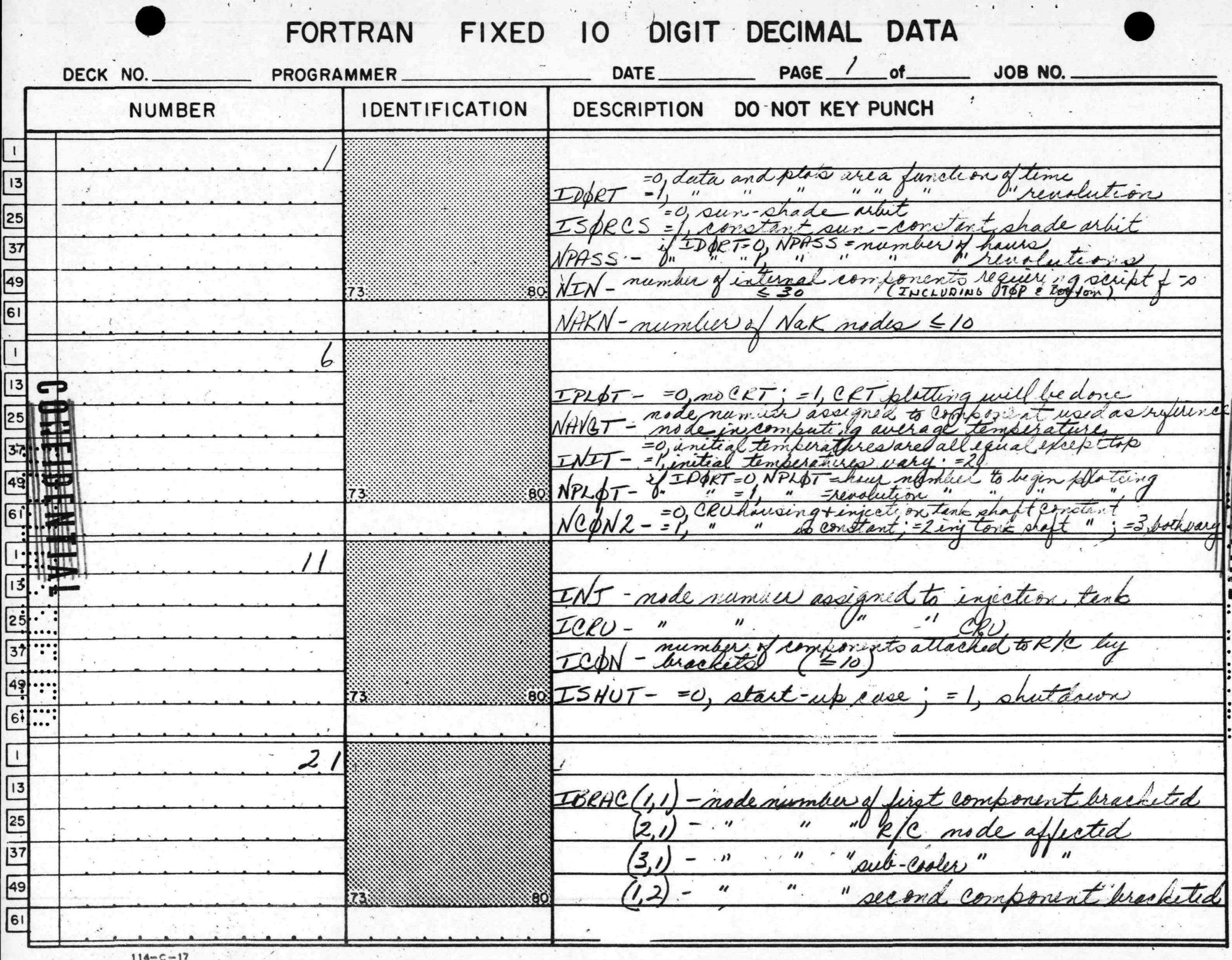




\section{FORTRAN FIXED 10 DIGIT DECIMAL DATA}

DECK NO.

PROGRAMMER

DATE

PAGE 2 of

JOB NO.

\begin{tabular}{|c|c|c|c|}
\hline & NUMBER & IDENTIFICATION & DO NOT KEY PUNCH \\
\hline \multicolumn{4}{|l|}{1} \\
\hline 13 & & & . \\
\hline 25 & & & - \\
\hline 37 & & & ! \\
\hline 49 & & 73 & 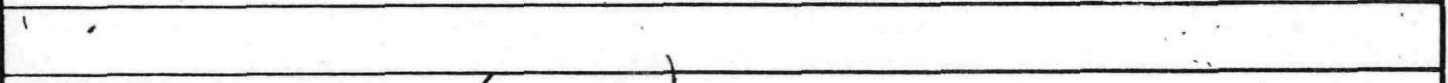 \\
\hline 61 & $?$ & & ete to IBRAC $(3, I C D N)$ \\
\hline 16 & 9.1 & & $\overline{7}$ \\
\hline 监貄 & & & DiInie-time iviermint disirid in minutiv \\
\hline 25 & & & Amere (1)- me of $\mathrm{K} / \mathrm{C}$ nodes \\
\hline 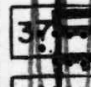 & - & & Amicre (2) - nie of cub-carler nodea \\
\hline $4 e^{2}=$ & & 13 & $A K(1)-K_{a}$ of $\mathrm{el} / \mathrm{e}$ modio \\
\hline 6: & & & $A K(2)$ - Ka of sub-coolerinsdes \\
\hline i. & 96 & & \\
\hline 13. & & & 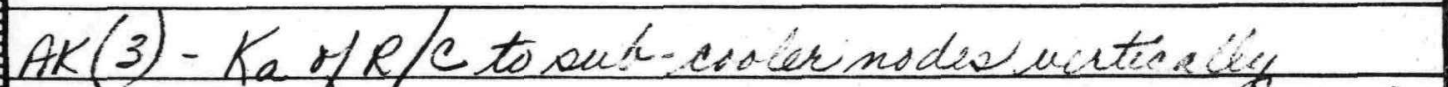 \\
\hline $25:-$ & & & 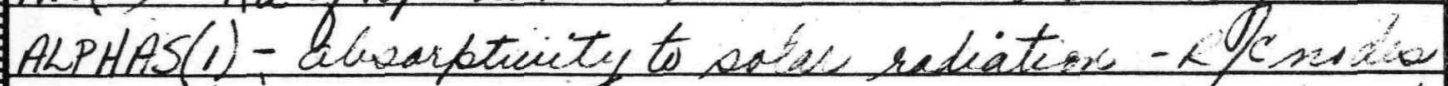 \\
\hline $37 \cdot:$ & & & "J" " "sute"enounded \\
\hline $4:-:$ & & & iryto themal radiaty in \\
\hline Ear:: & & & 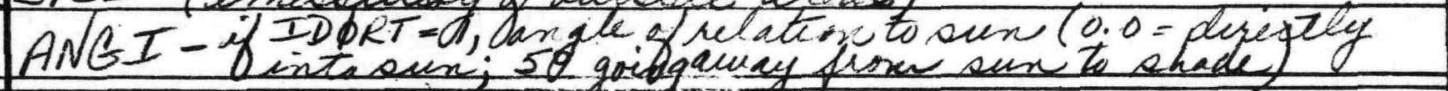 \\
\hline 1 & 10.1 & & \\
\hline 13 & & & 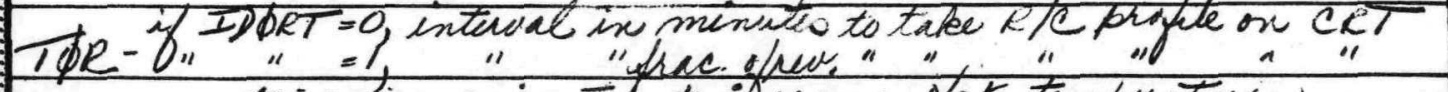 \\
\hline 25 & & & 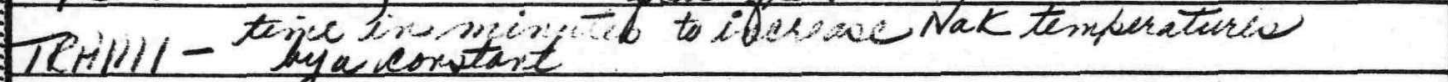 \\
\hline 37 & & & ThHin2-time ixminutio to binix Nak nodw ramp \\
\hline 49 & & 3 & Tinms-" " " "end " \\
\hline 61 & $\therefore$ & . & TeAm4 - "." " "begin ramp for top \\
\hline
\end{tabular}




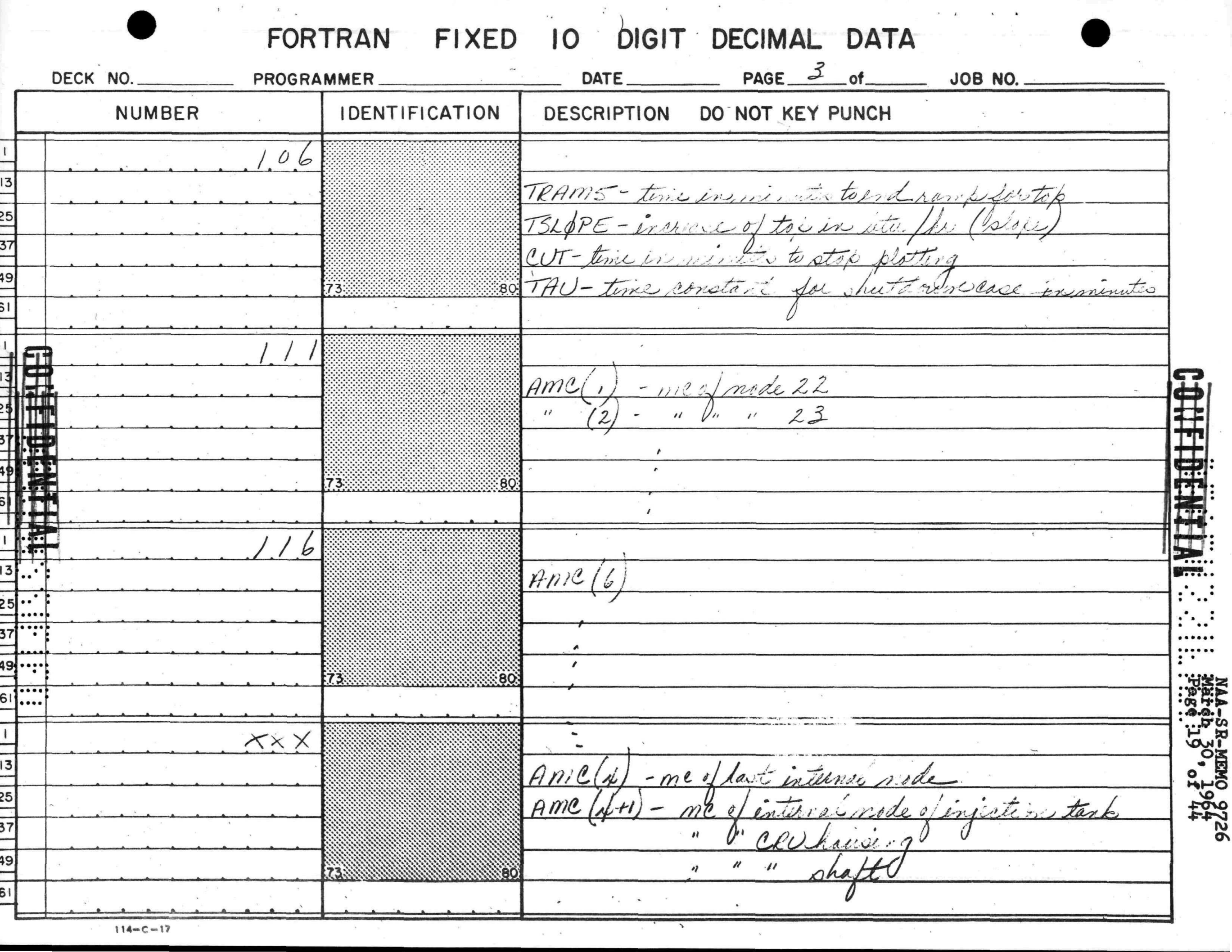




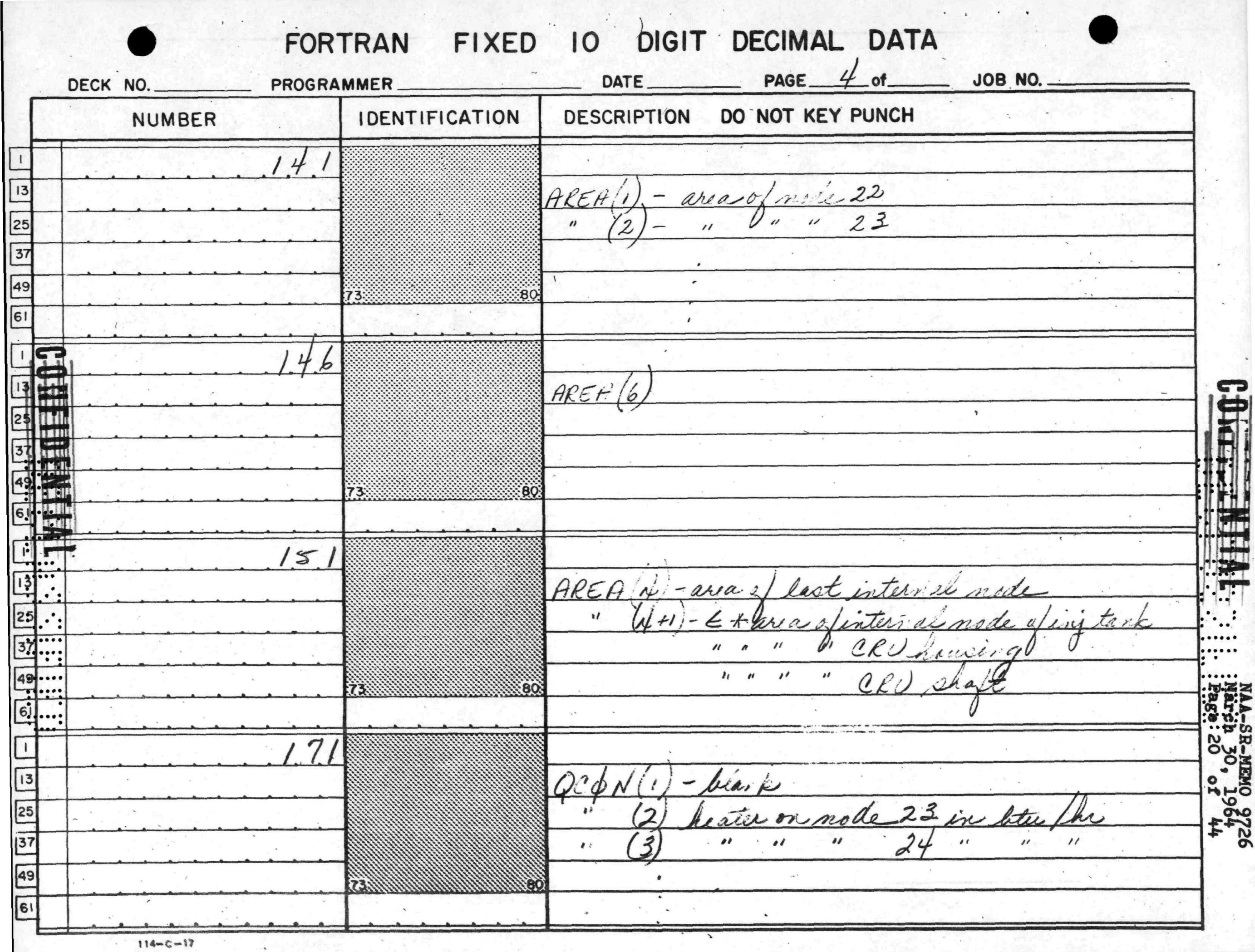


FORTRAN FIXED 10 DIGIT DECIMAL DATA

DECK NO.

PROGRAMMER

DATE

PAGE 5 of

JOB NO.

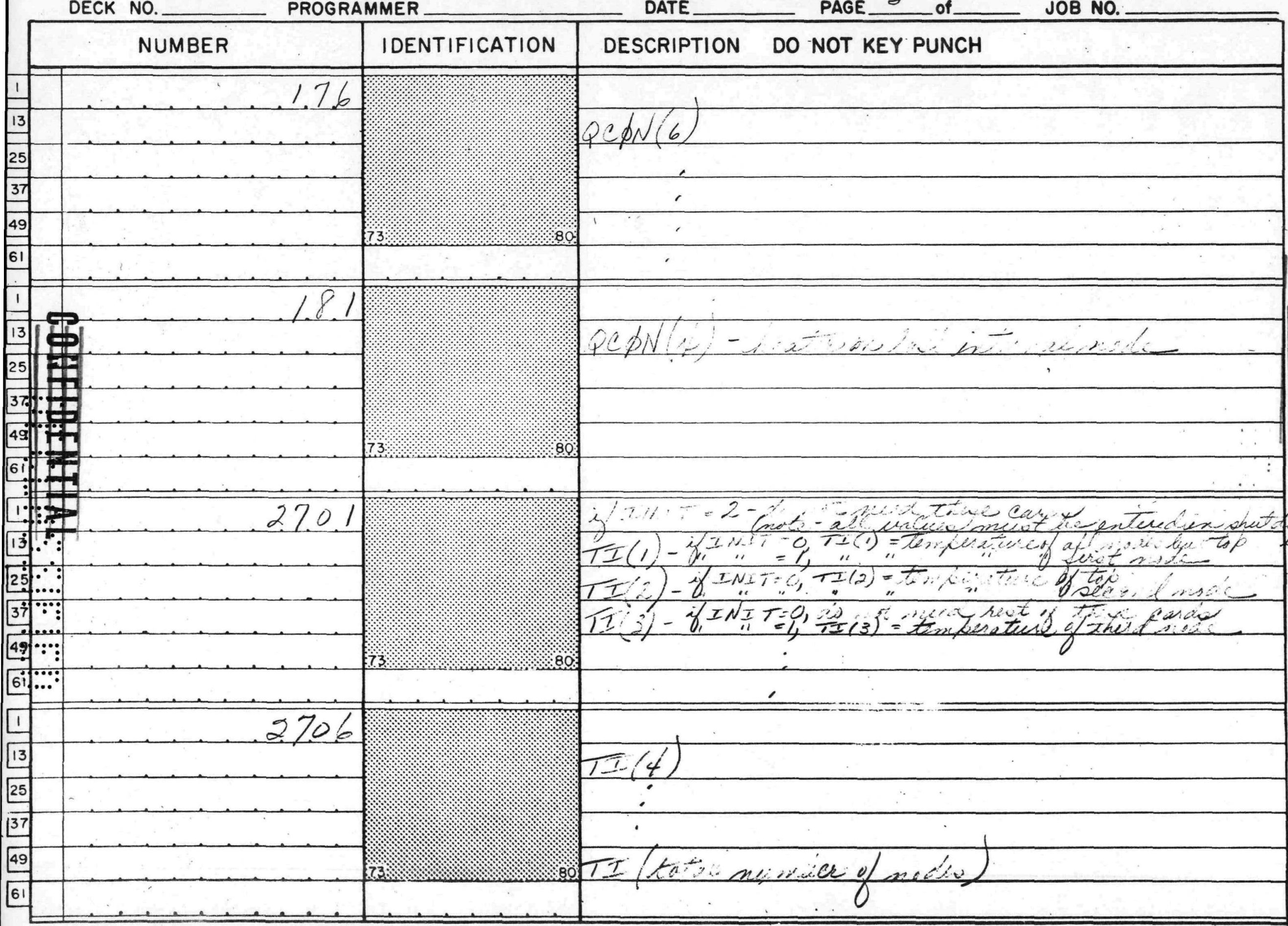




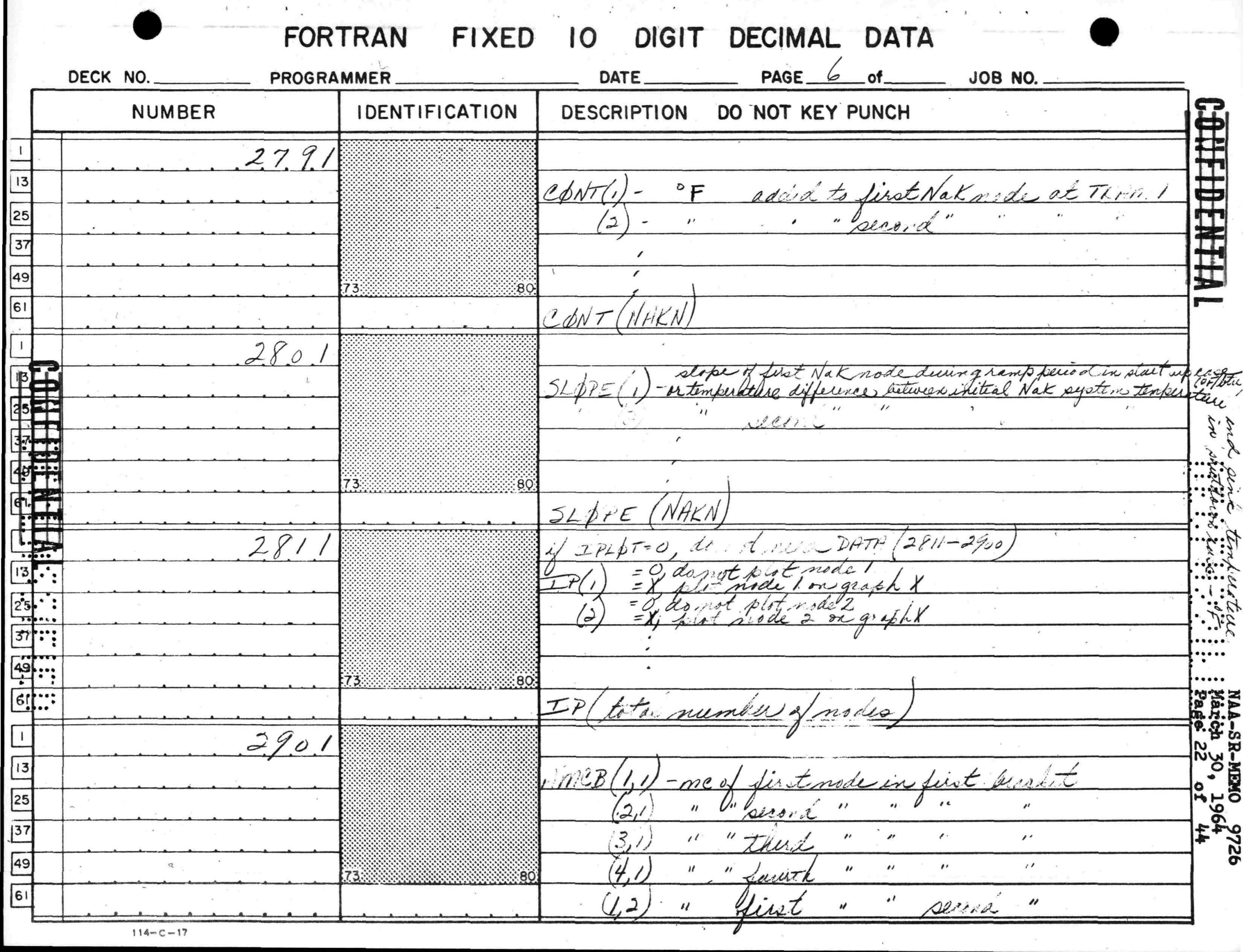




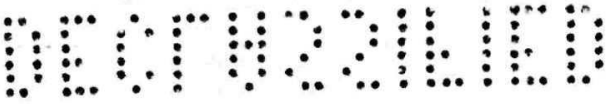

CHOENTAL

AVERAGE R/C TEMPERATURE TRANSIENT ORBIT
NAA-SR-MEMO 9726

March 30, 1964

Page 25 of 44

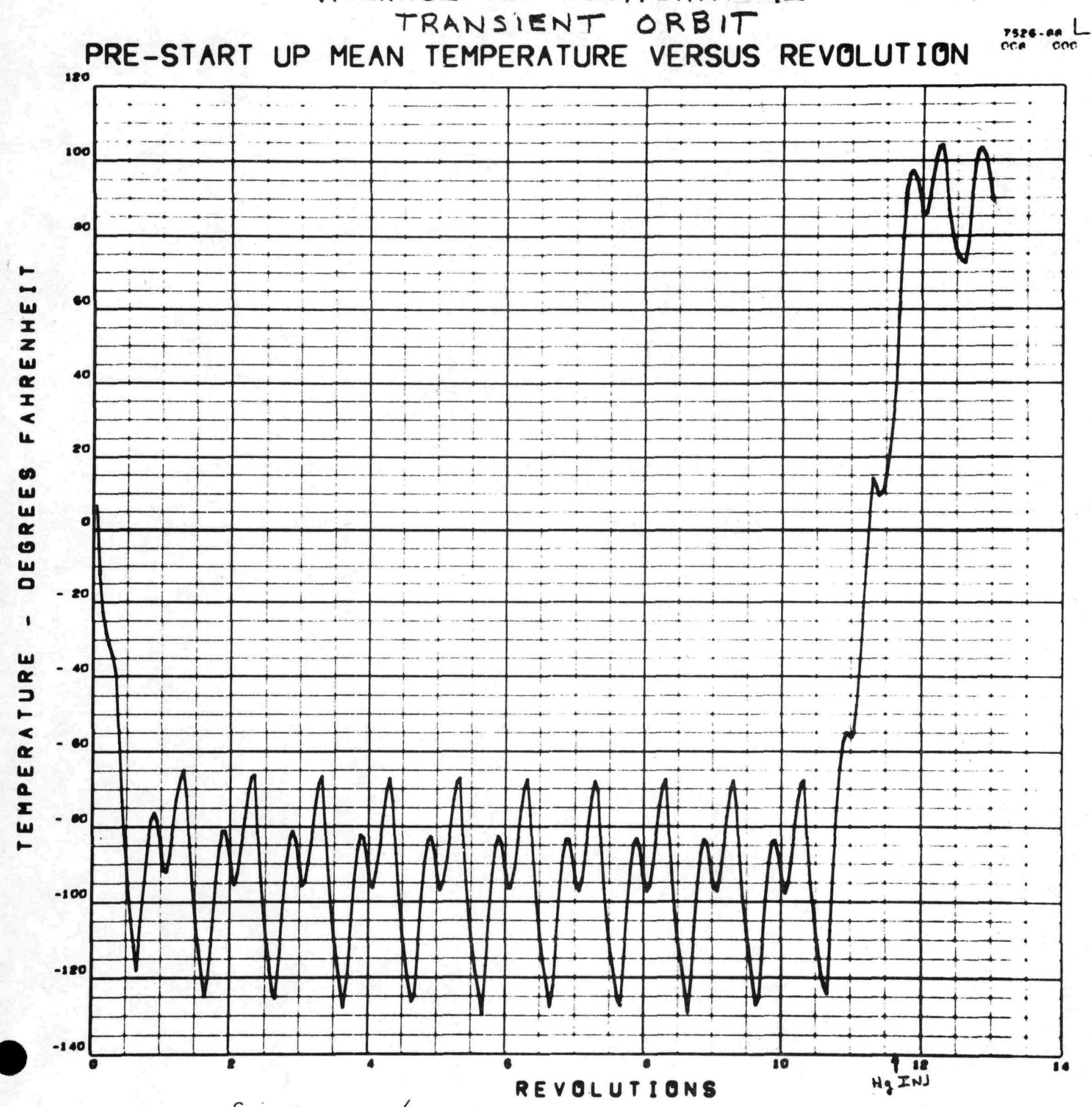




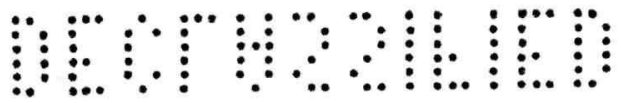

\section{COAFIDENTAL}

R/C TEMPERATURE DISTRIBUTION

TRANSIENT ORBIT

TEMPERATURE DISTRIBUTION OF R/C NODES

NAA-SR-MEMO 9726

March 30, 1964

Page 26 of 44

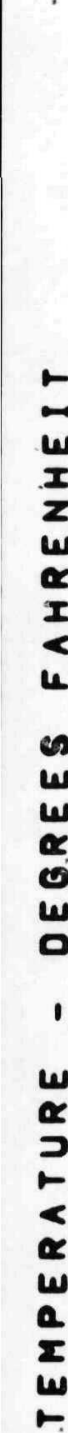

100

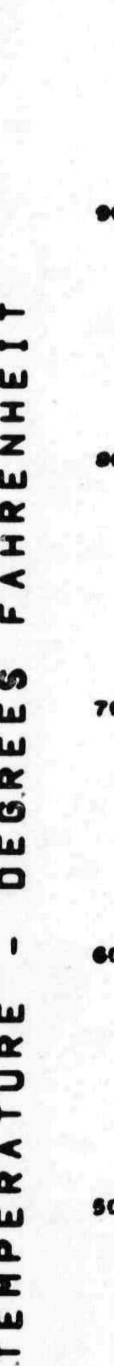

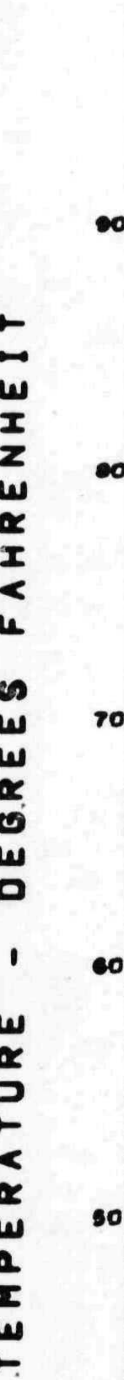
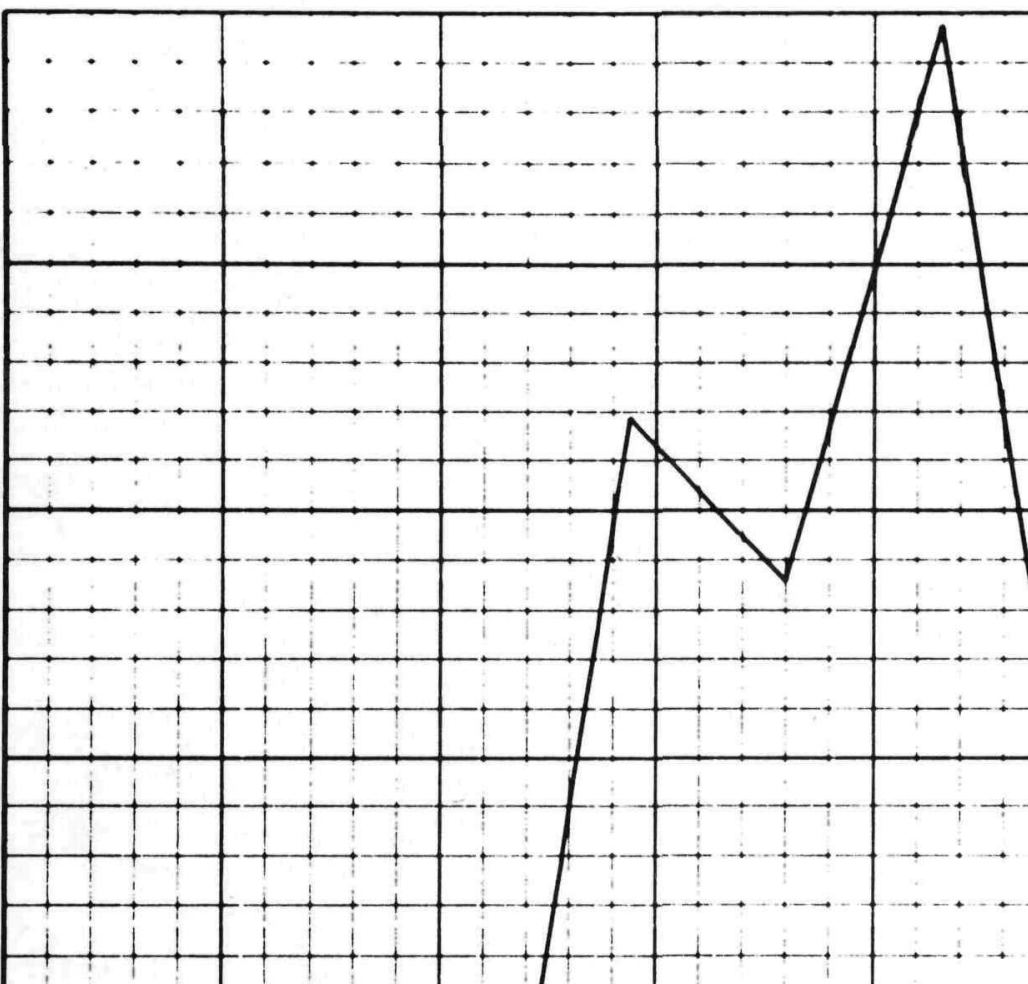

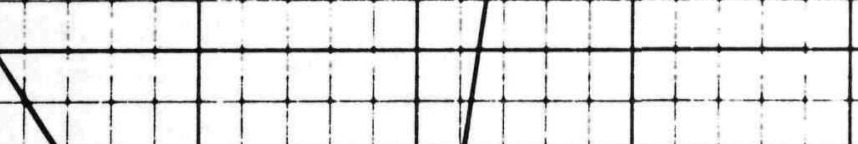

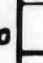

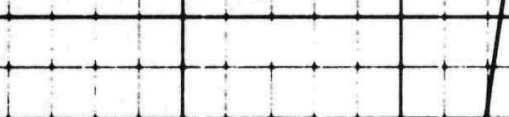

$\left(\begin{array}{c}1 \\ 1 \\ 1 \\ 1\end{array}\right.$

$\rightarrow$
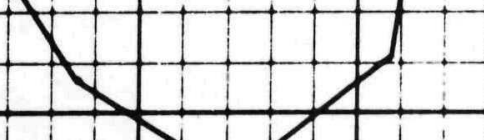

17.1.
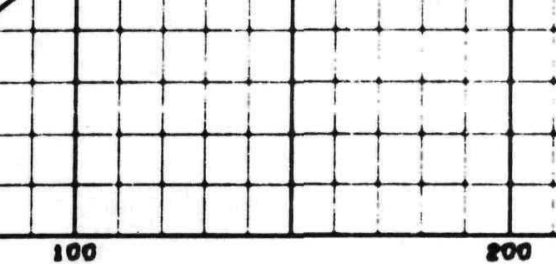

CIRCUMFERENCE

REVOLUTION $8=11.88$

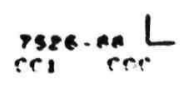

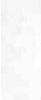

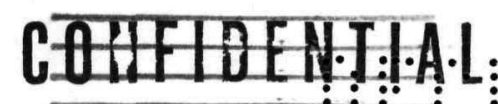

$\therefore \because \because \because: \because \vdots:$ :F! $\because$ UURE 3 
界

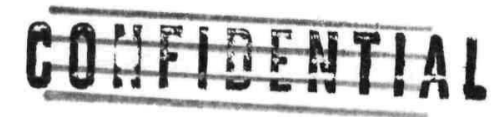

TRANSIENT ORBIT

NAA-SR-MEMO 9726

Nareh 30, 1964

Page 27 of 44

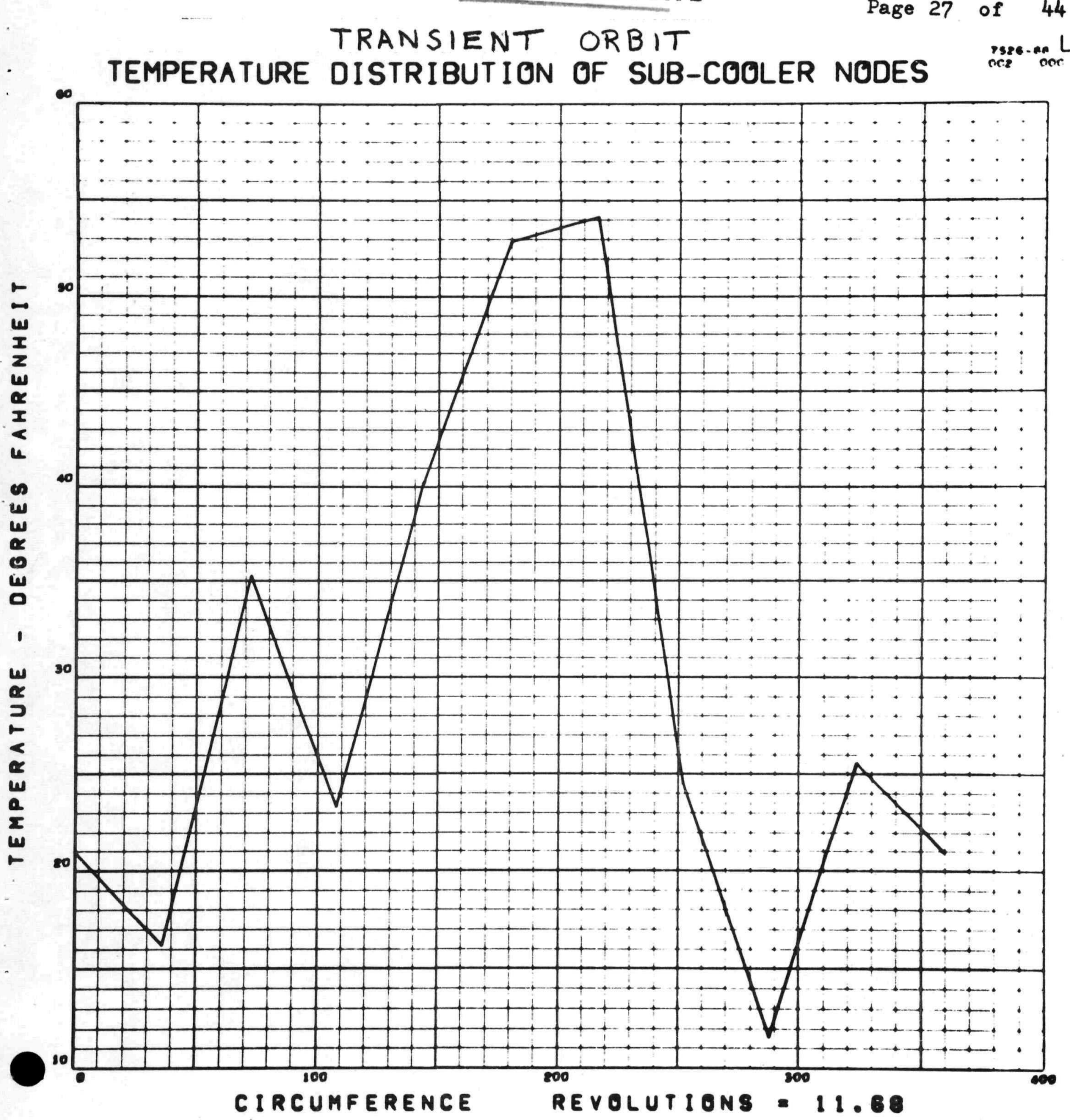

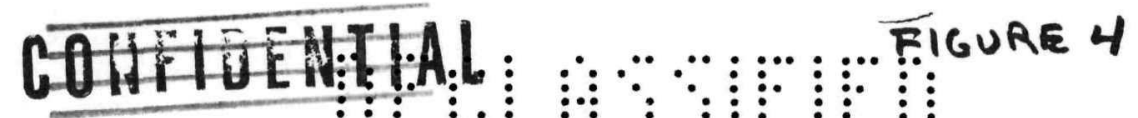




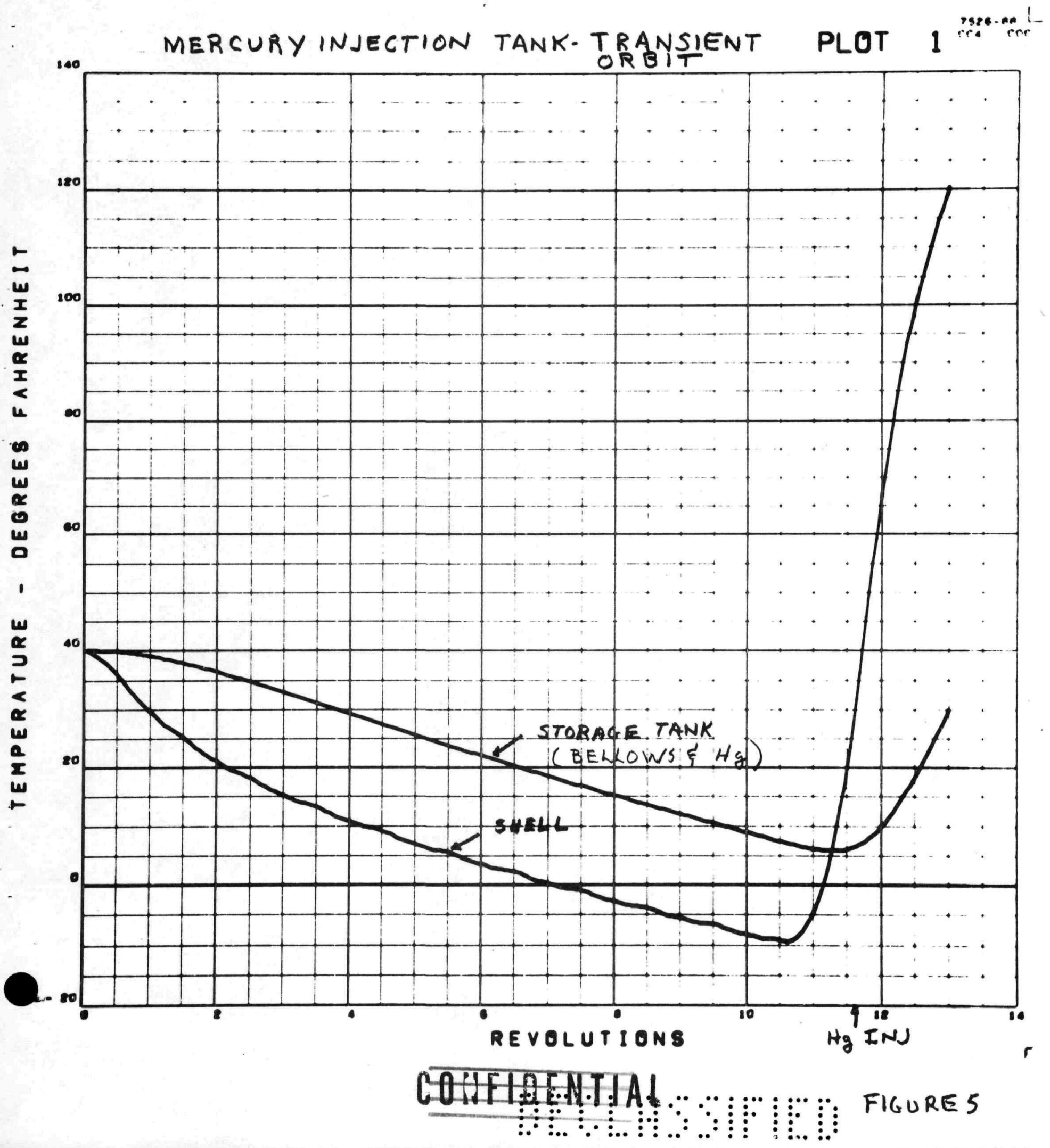




\section{HOENIAL}

CRU - TRANSIENT ORBIT
NAA-SR-MEMO 9726

March 30, 1964

Page 29 of 44

PLOT 2

100

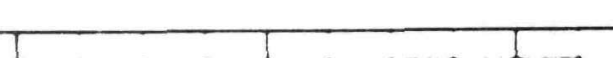




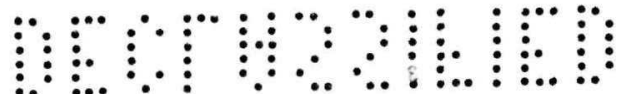

\section{COIAITERTIAL}

Hg REGULATOR \& REGULATOR LINE
NAA-SR-MEMO 9726

March 30, 1964

Page 30 of 44

PLOT $3^{\text {issenen en }}$

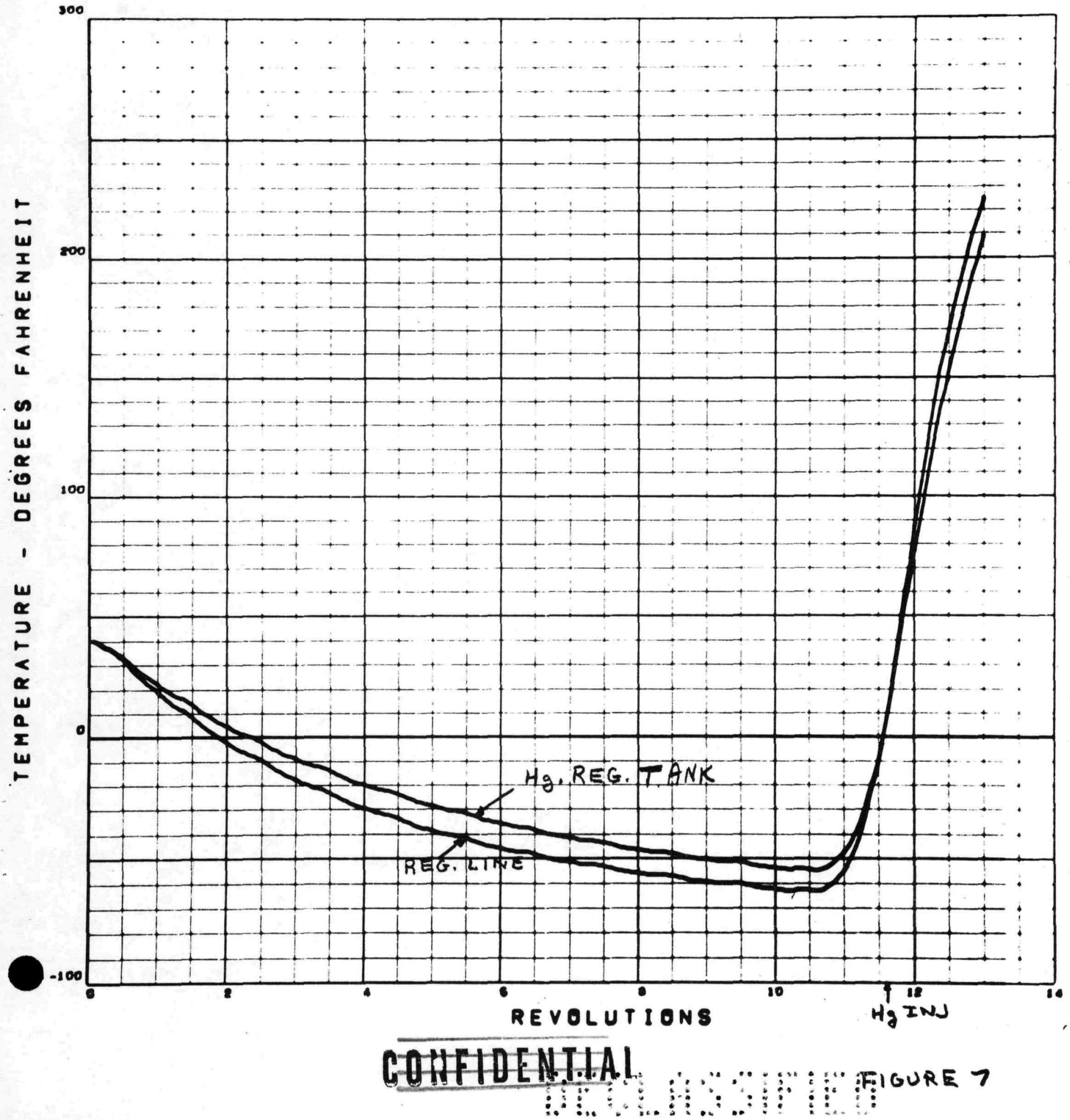




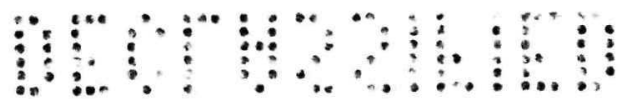

\section{COAFEEHTIAL \\ NAA-SR-MEMO 9726 \\ March 30, 1964 \\ Page 31 of 44}

PCS COMPONENTS - TRANSIENT ORBIT PLOT 4

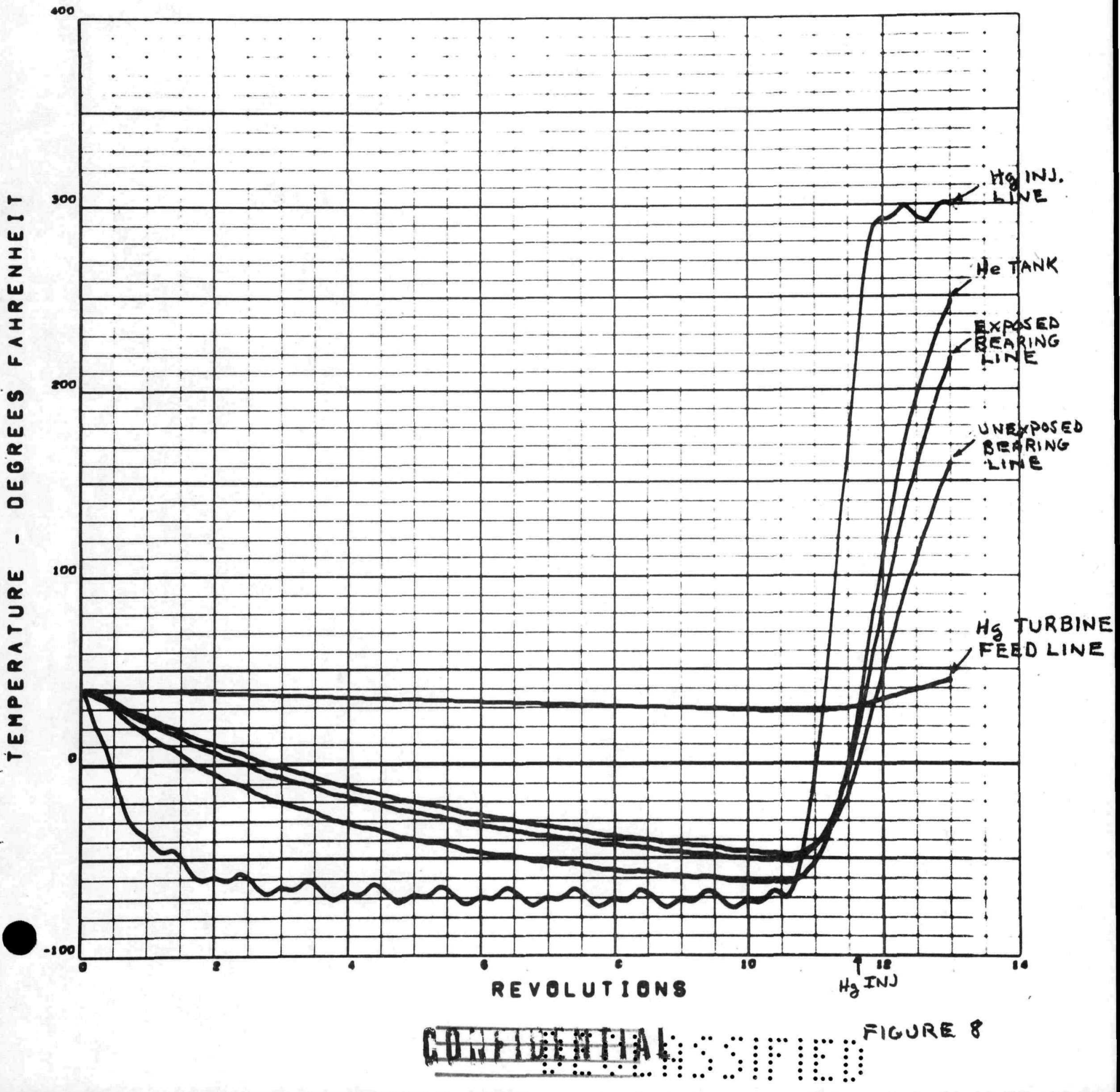




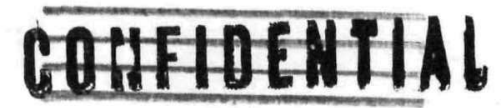

MERCURY VAPOR RISER - TRANSIENT ORBIT
NAA-SR-MEMO 9726 March 30, 1964

Page 32 of 44

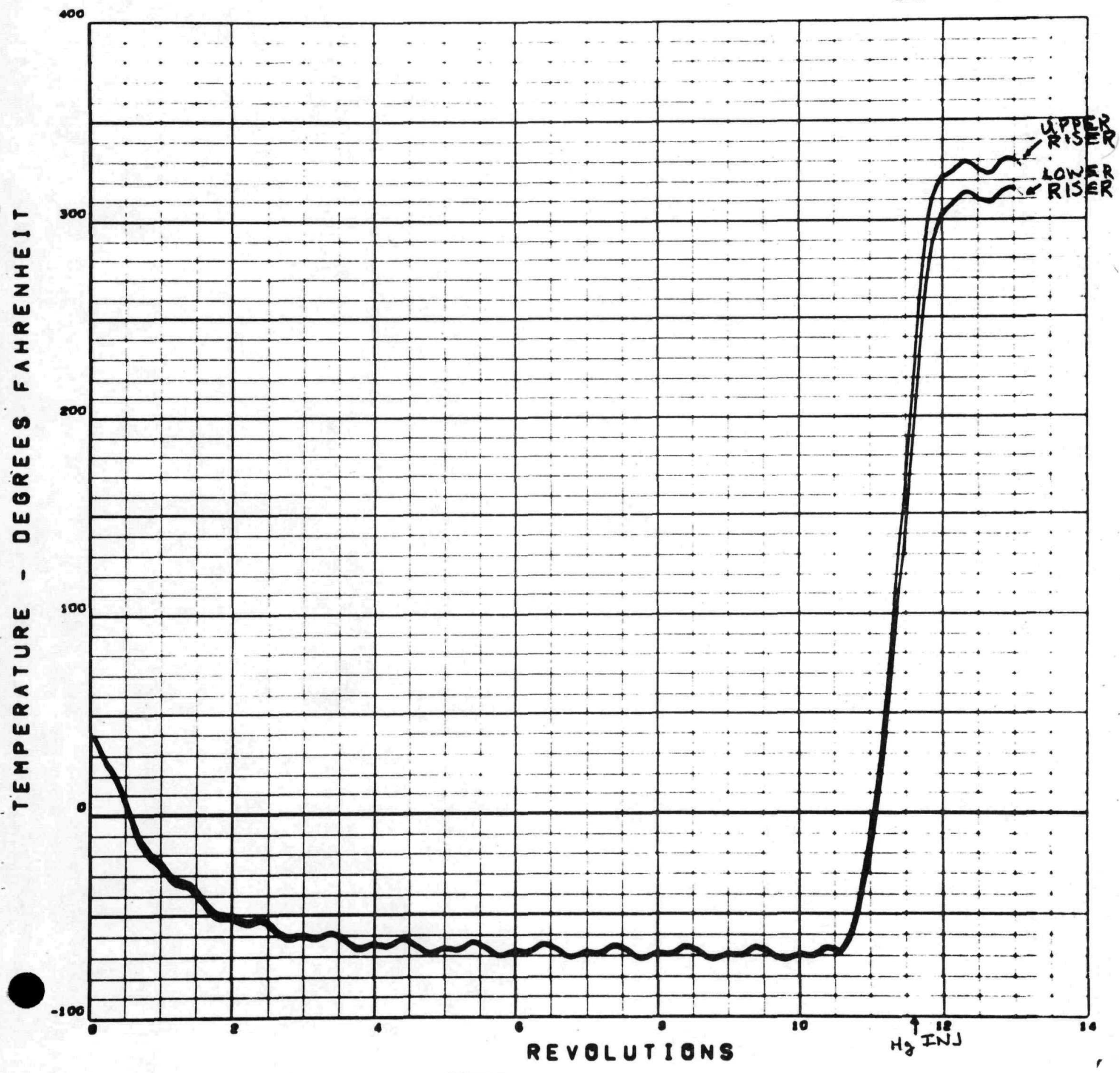

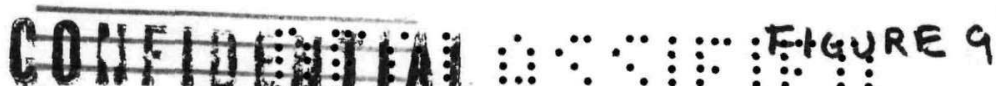




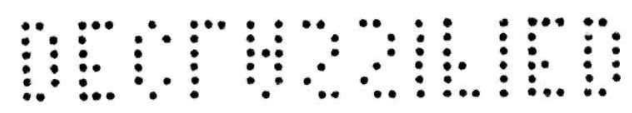

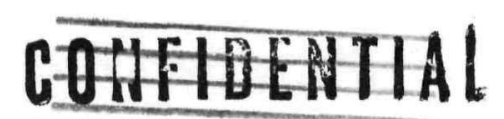

AVER AGE R/C TEMPERATURE Page 33 of 44 CONSTANT SUN-CONSTANT SHADE ORBIT PRE-START UP MEAN TEMPERATURE VERSUS REVOLUTION

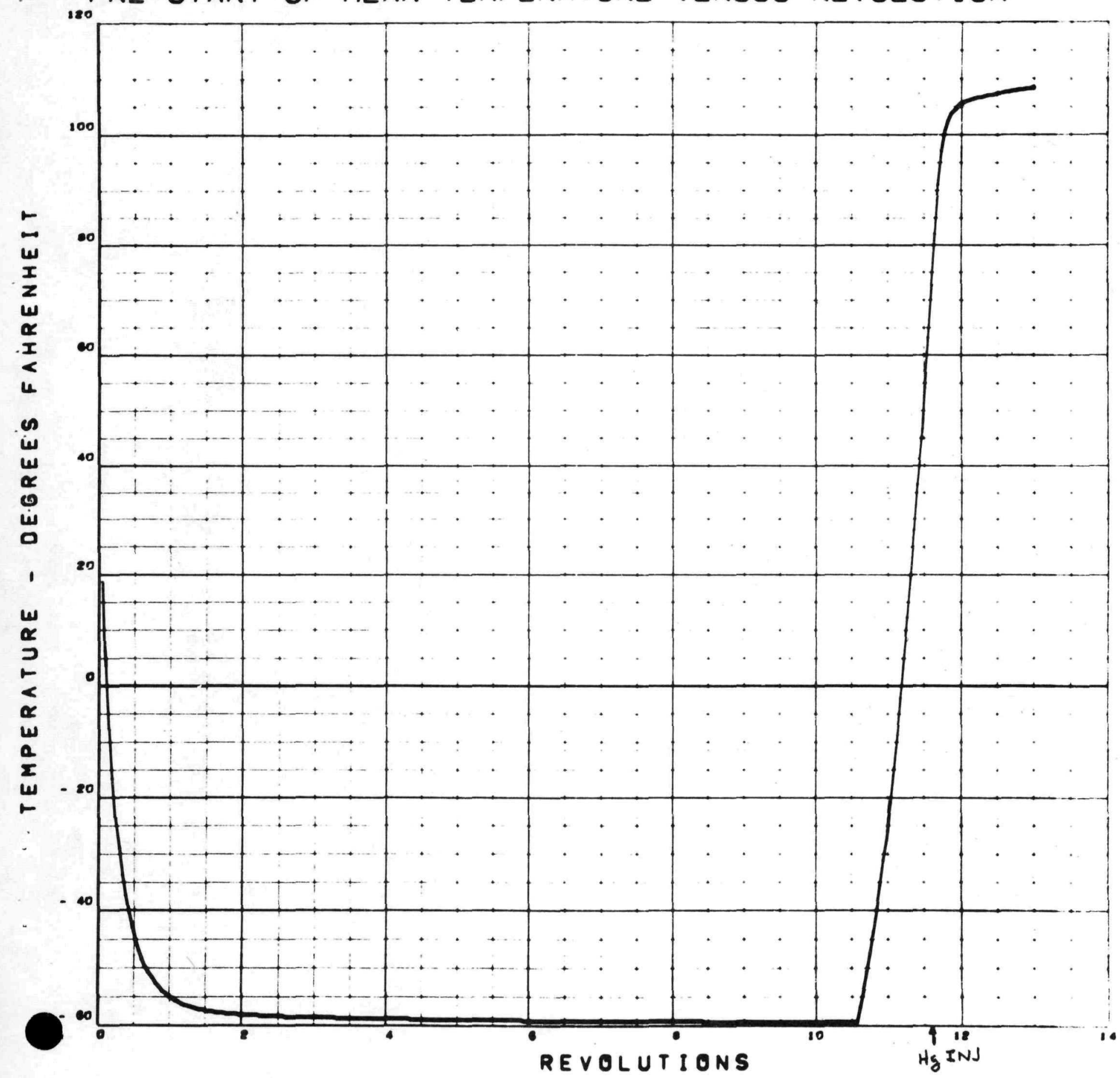


COIIFIDENTH!

NAA-SR-MEMO 9726

March 30, 1964

Page 34 of 44

CONSTANT SUN-CONSTANT SHADE ORBIT TEMPERATURE DISTRIBUTION OF R/C NODES

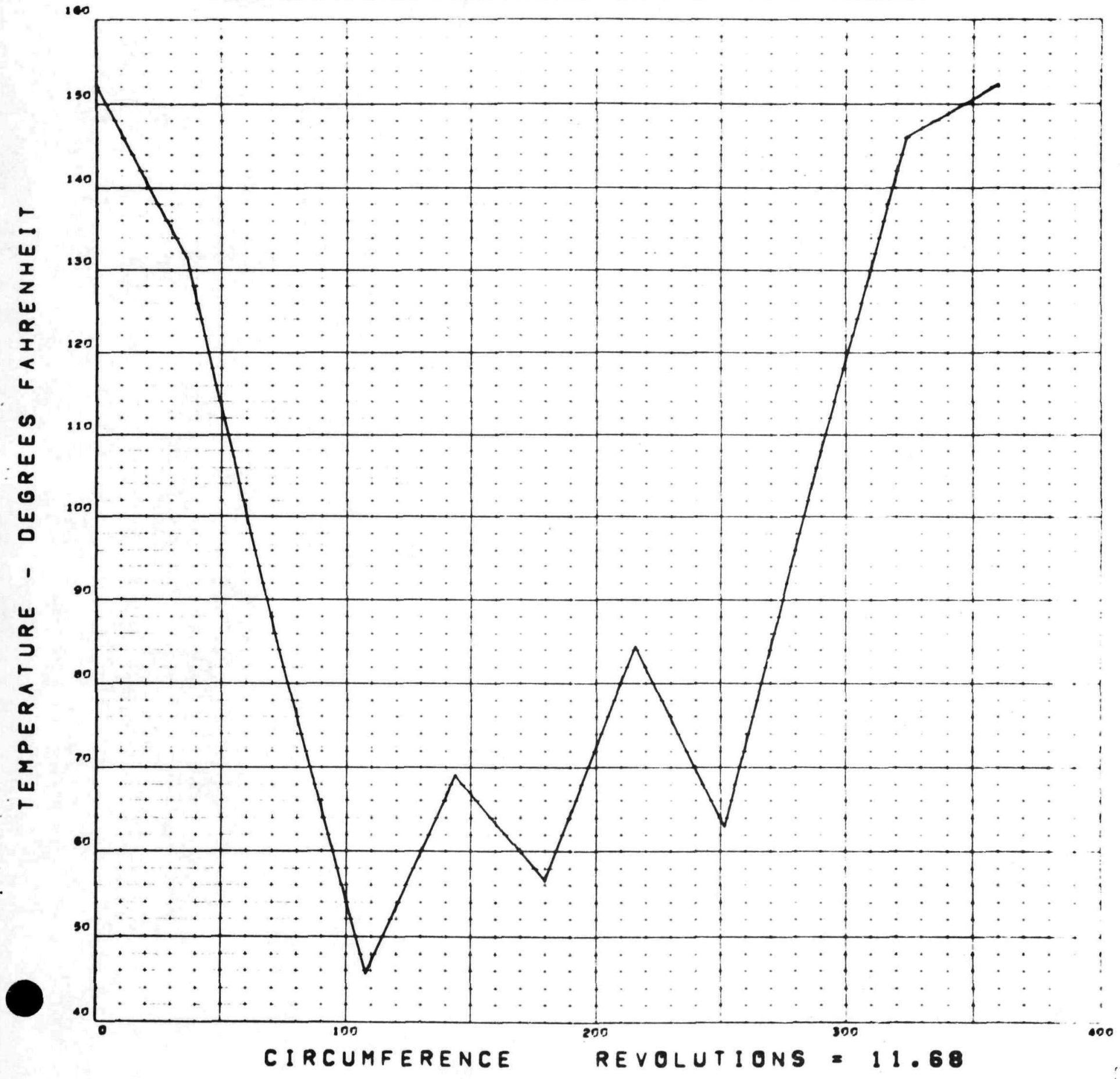




\section{COIFFEENTIAL}

NAA-SR-MEMO 9726

March 30, 1964

Page 35 of 44

CONSTANT SUN-CONSTANT SHADE ORBIT

TEMPERATURE DISTRIBUTION OF SUB-COOLER NODES

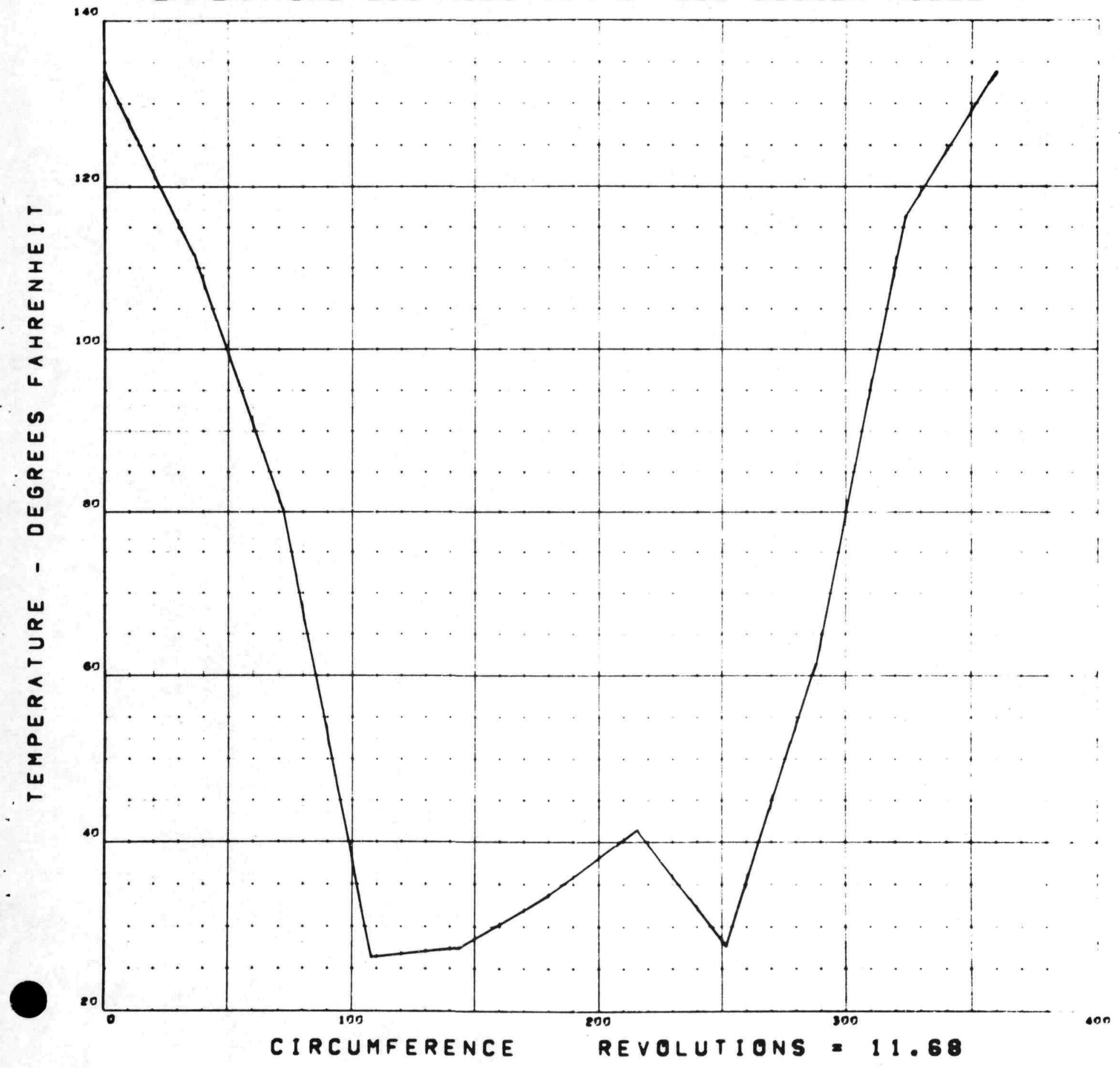

COLIOENTIAL: : 


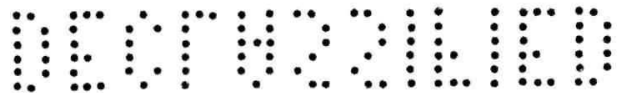

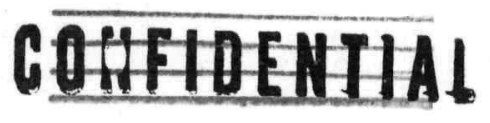

NAA-SR-MEMO 9726

March 30, 1964

Page 36 of 44

MERCURYINJECTION TANK-CONSTANT SUN-CONSTANT SHAPE PLOT $1 \cdots$

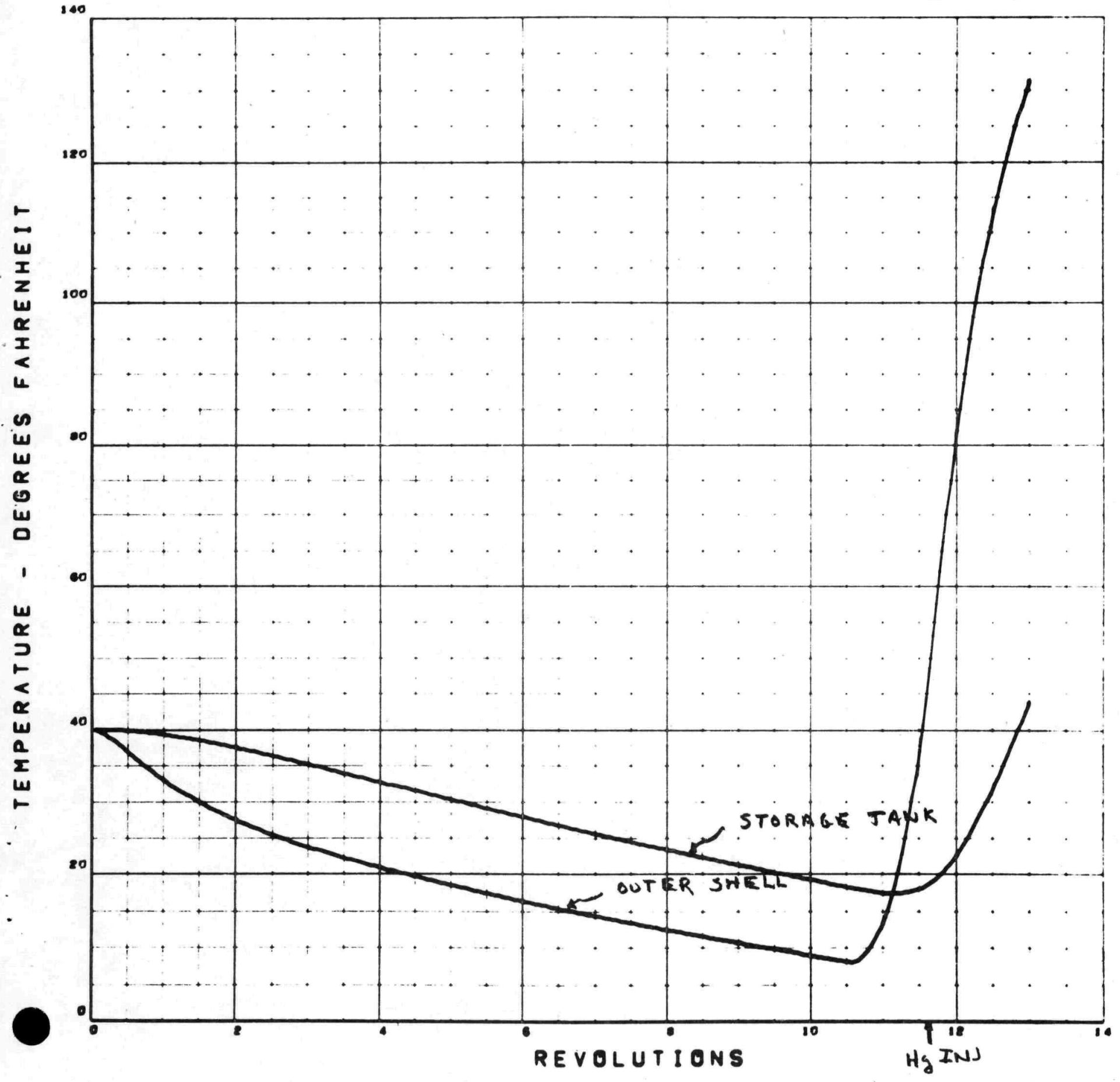

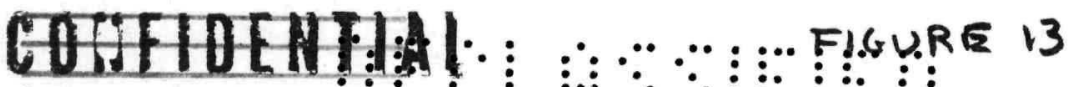




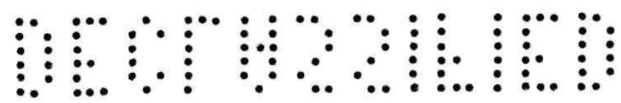

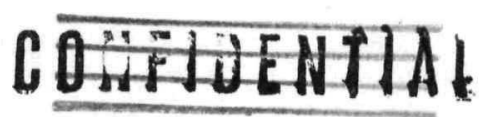

NAA-SR-MEMO 9726

March 30, 1964

Page 37 of 44

CRU' CONSTANTSUN-CONSTANT SHADE ORBIT

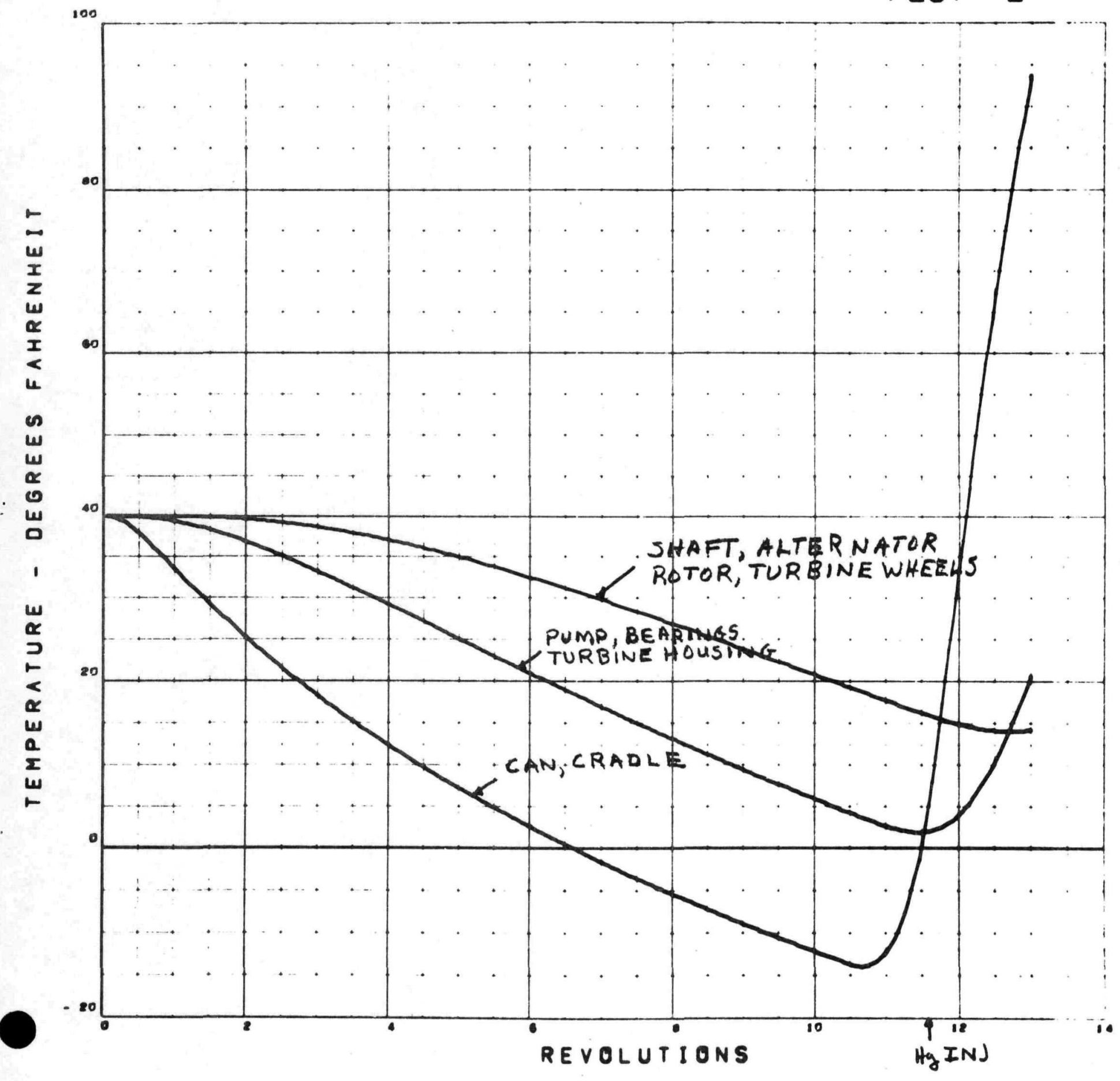

2.+44: 


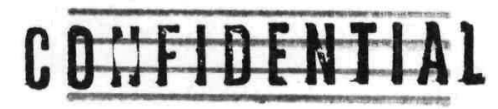

NAA-SR-MEMO 9726

March 30, 1964

Page 38 of 44

Hg REGULATOR \& REGULATOR LINE CONSTANT SUN-CONSTANT SHADE PLOT 3

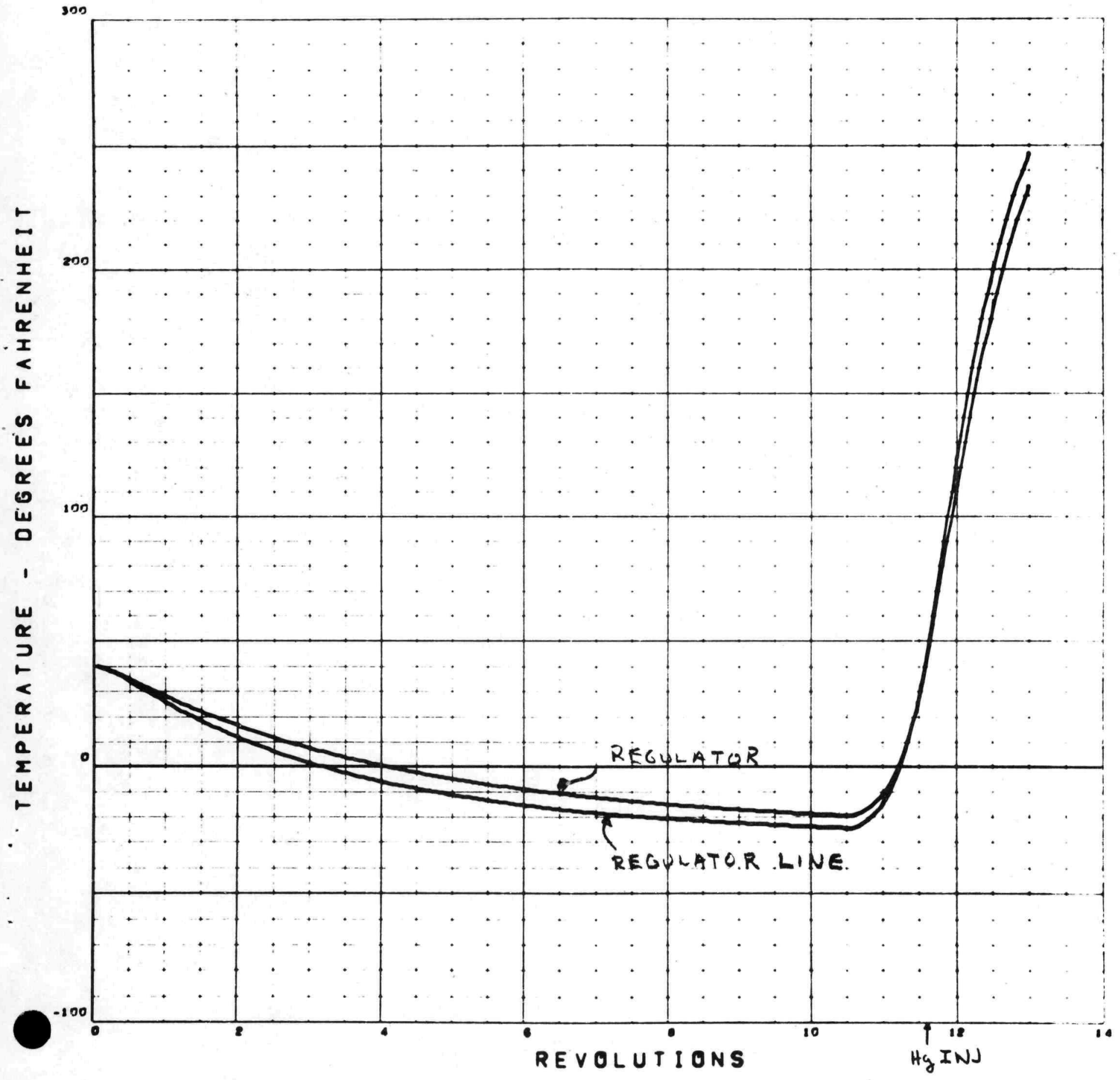


Cotidal

PCS COMPONENTS CONSTANT SUN-CONSTANT SHADE ORBIT

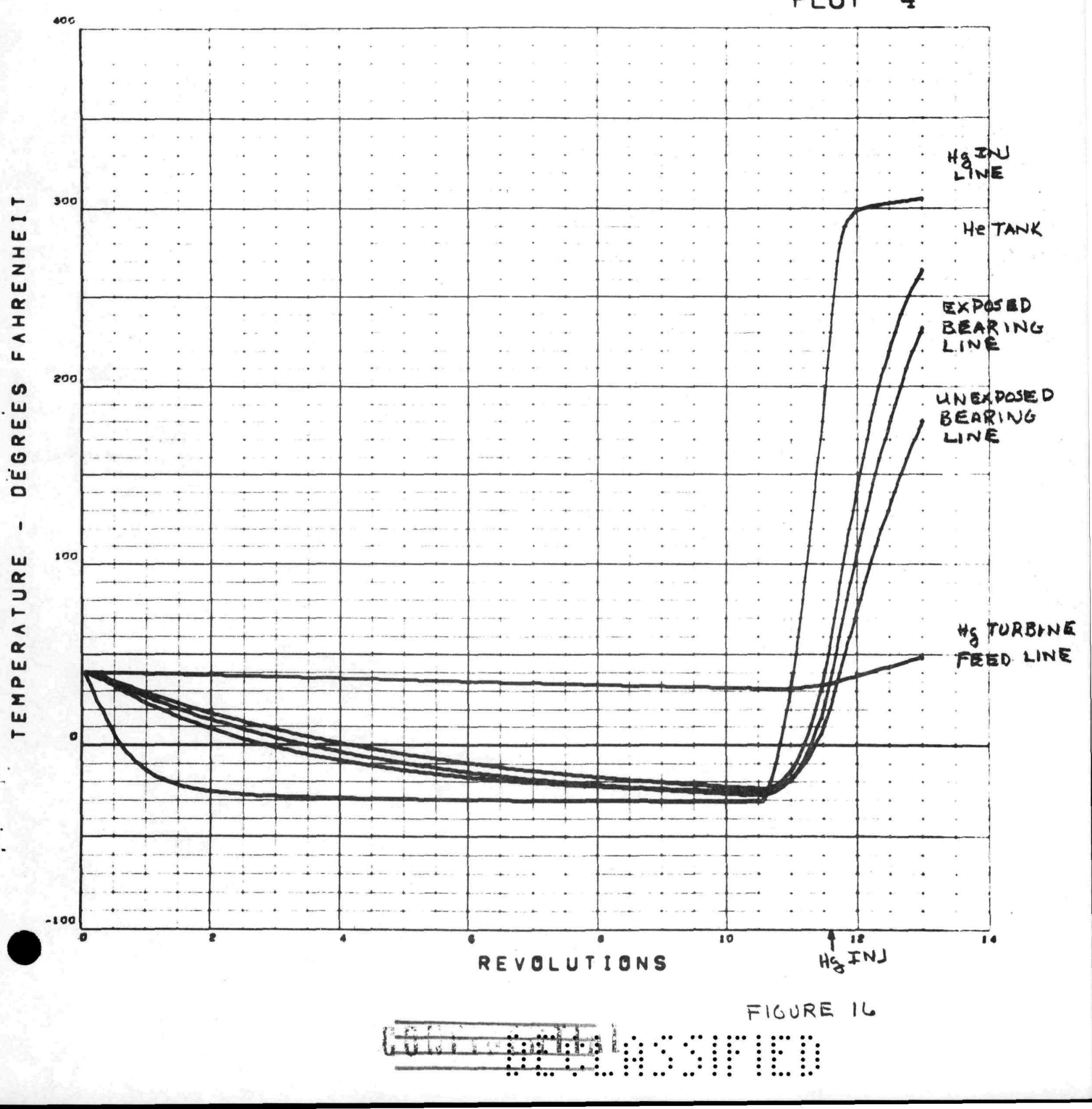


C
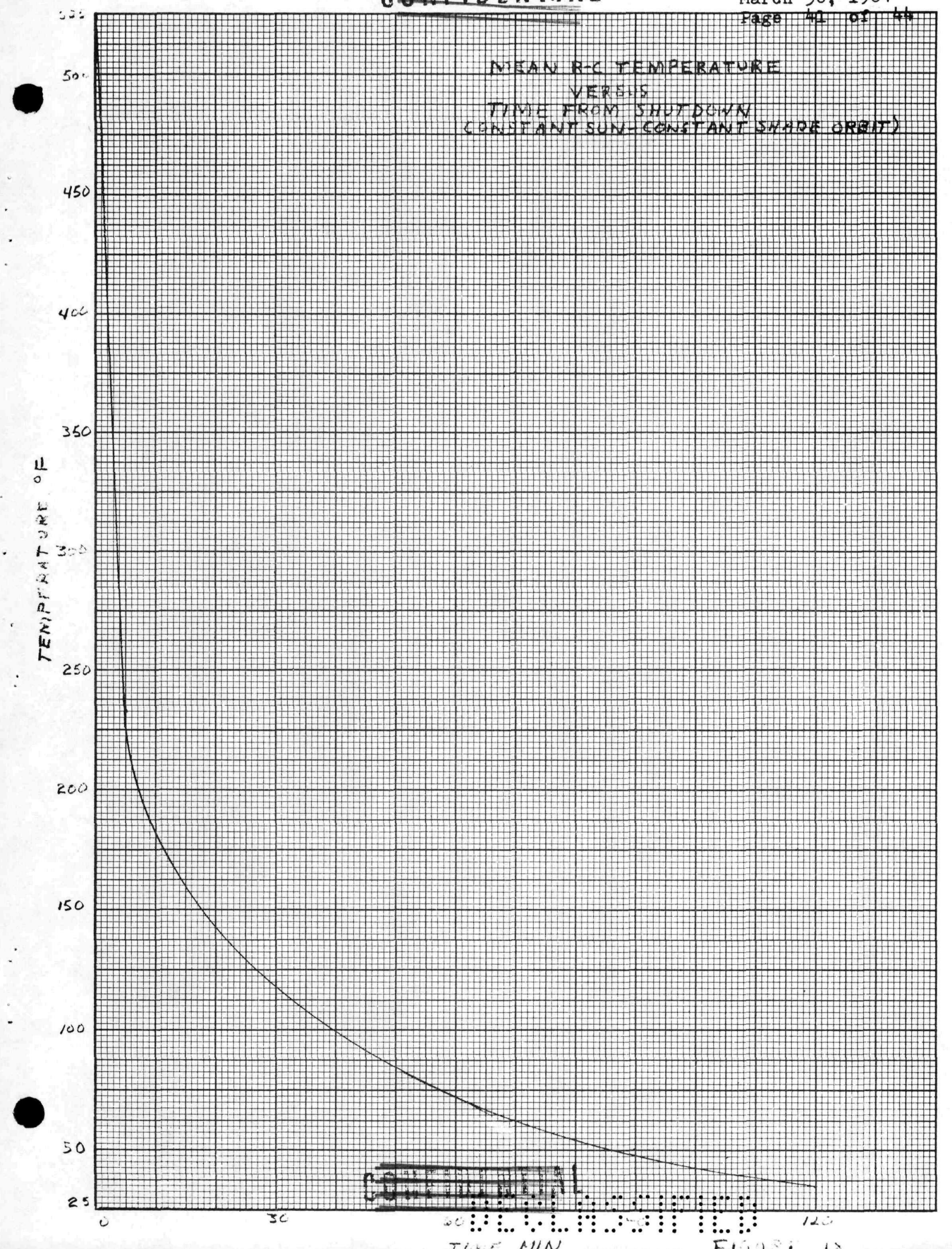


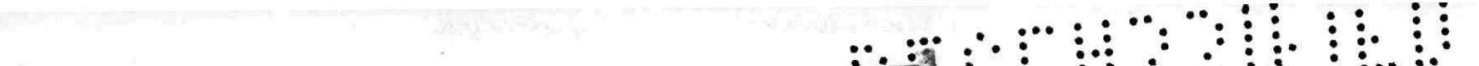

UNCLASSIFIED, fAn

380

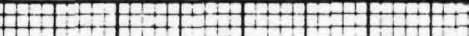

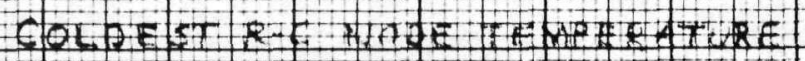
Vecsus

T51.101

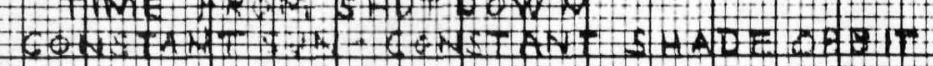

30

$\stackrel{4}{0}$

0200

100

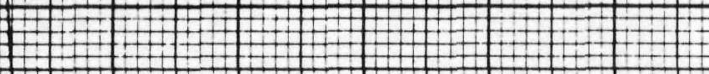

>

1.

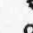

$\sum_{4}^{c}$

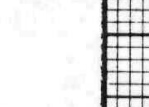

$+$

$\frac{i}{4}$

$+$

ㄴ
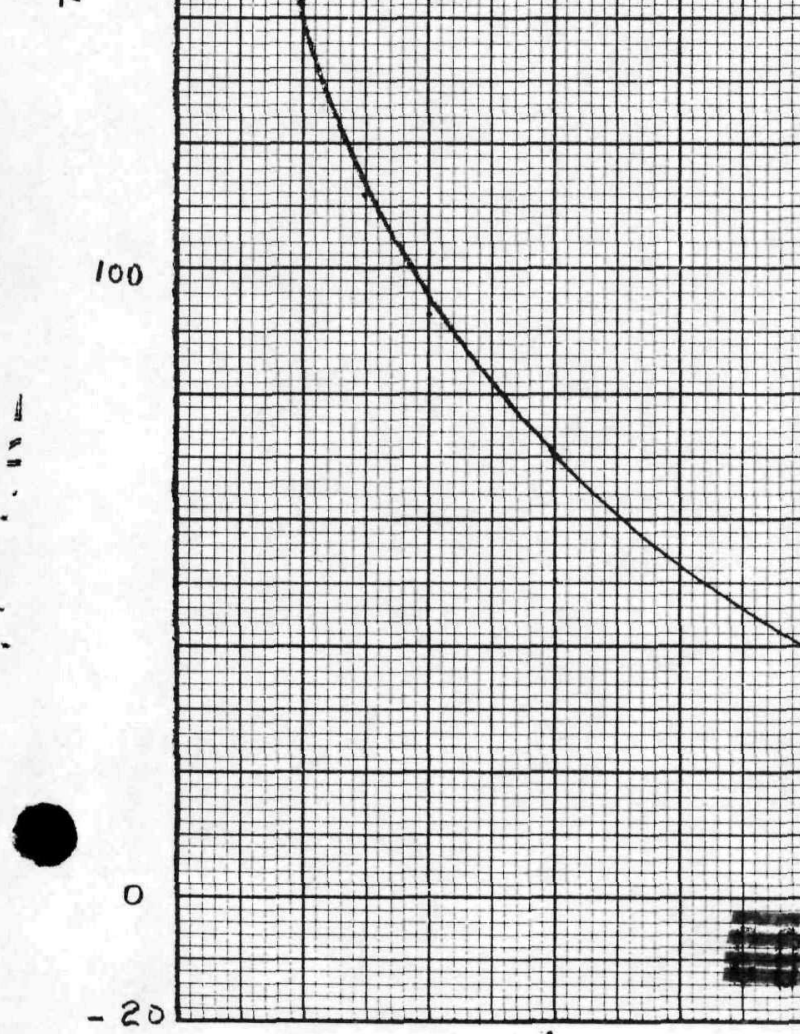


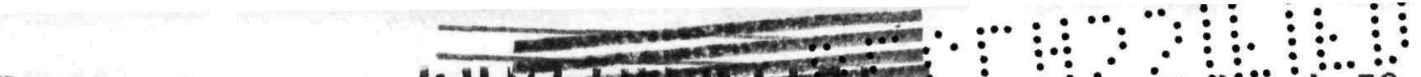

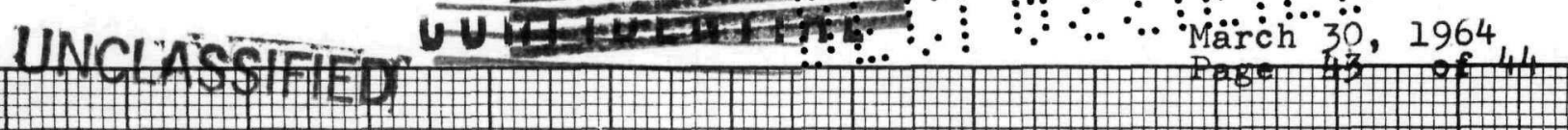

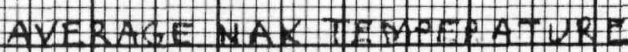
VERSTLS

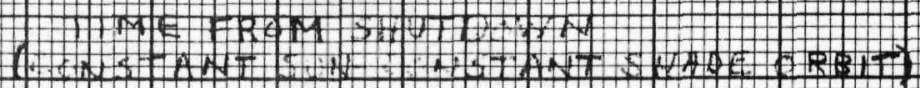

120

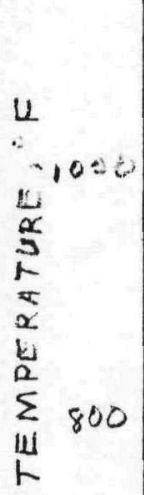

6<smiles>CCC1CC1</smiles>

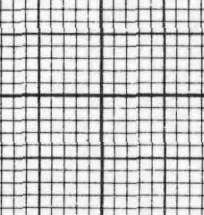

$+$ 


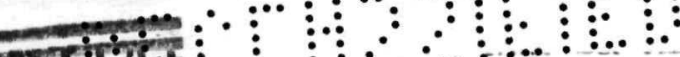 \\ C \\ UNCLASSIFIED}

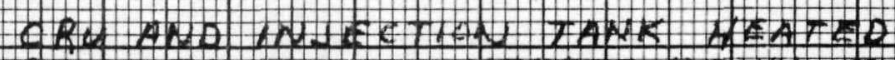

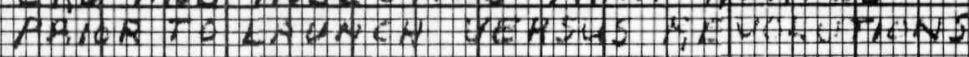

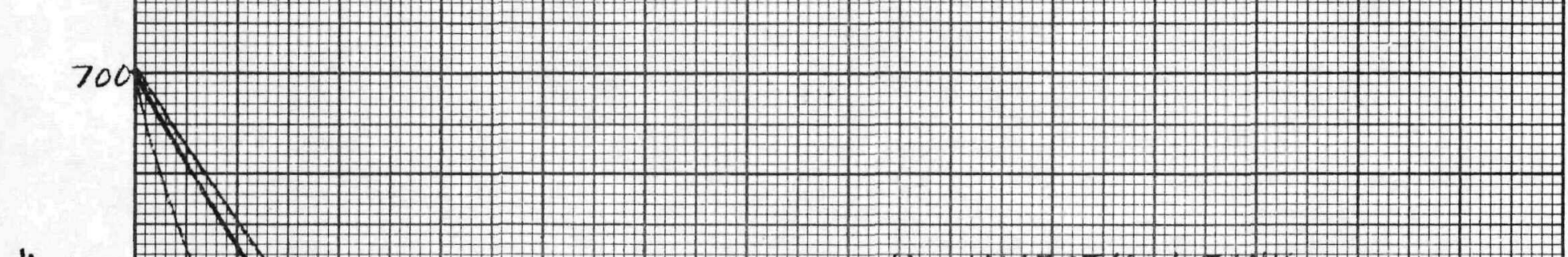

11600

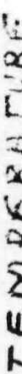

200

50

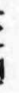

40

300 a) injectran tants

2) CRU - CAN CAADLE

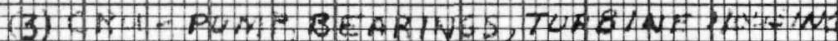

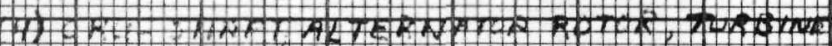
whaths

100

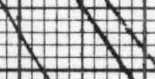

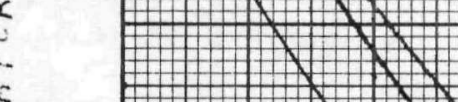

\#杖)
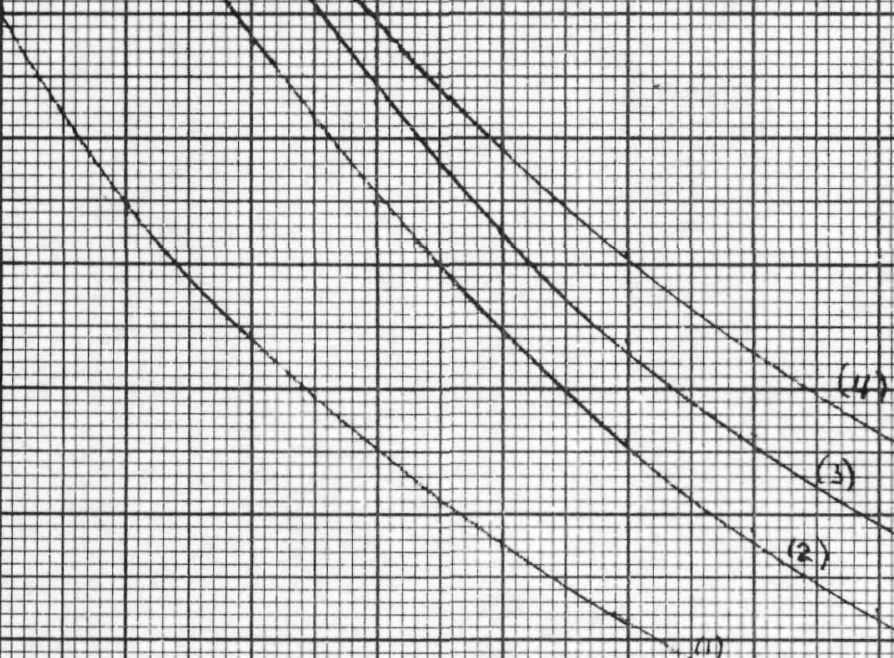